\title{
Functional Diversity of Mammalian Sialyltransferases
}

\author{
哺乳類シアル酸転移酵素の機能多様性 \\ Takashima, Shou ${ }^{1}$; and Tsuji, Shuichi ${ }^{2}$ \\ ${ }^{1}$ The Noguchi Institute, 1-8-1 Kaga, Itabashi, Tokyo 173-0003, Japan \\ ${ }^{2}$ Institute of Glycoscience, Tokai University, 4-1-1 Kitakaname, Hiratsuka, Kanagawa 259-1292, Japan \\ FAX:81-3-3964-5588, E-mail: staka@noguchi.or.jp
}

(Received on June 30, 2011, accepted on September 8, 2011)

Key Words: sialyltransferase, sialic acid, sialylglycoconjugate, ganglioside, glycoprotein

\begin{abstract}
Sialic acids are negatively charged acidic sugars. Sialyltransferases are enzymes that catalyze the synthesis of sialylglycoconjugates, which play important roles in various biological processes. Twenty members of the mammalian sialyltransferase superfamily have been identified to date. These enzymes are grouped into 4 families according to the type of carbohydrate linkage they synthesize: $\beta$-galactoside $\alpha 2,3$-sialyltransferases (ST3Gal-I-VI), $\beta$-galactoside $\alpha 2,6$-sialyltransferases (ST6Gal-I and -II), GalNAc $\alpha 2,6$-sialyltransferases (ST6GalNAc-I-VI), and $\alpha 2,8$ sialyltransferases (ST8Sia-I-VI). Each sialyltransferase has its specific function in the complicated mammalian body system. In this review, we describe the functional diversity of mammalian sialyltransferases on the basis of recent studies and discuss the necessity for 20 different sialyltransferases.
\end{abstract}

\section{A. Introduction}

Sialic acids (Sias)* are derivatives of the negatively charged acidic sugar neuraminic acid. Over 40 naturally occurring members of the sialic acid family have been discovered to date (1); $\mathrm{N}$-acetylneuraminic acid (NeuAc)*, $\mathrm{N}$-glycolylneuraminic acid (NeuGc), and deaminoneuraminic acid (KDN) are representative members of this family. The importance of these molecules is demonstrated by the fact that impairment of their biosynthesis is lethal to mice embryos (2). Sialic acids usually form the terminal ends of the carbohydrate groups of glycoconjugates. Because of their negative charge and their exposed positions on cellsurface molecules, they often function as key determinants of oligosaccharide structures that mediate a variety of biological
要 約

シアル酸は負電荷を有する酸性糖である。シアル酸転移 酵素は、様々な生命現象において重要な役割を果たしている シアル酸含有糖鎖の合成に関与する酵素である。現在までに 哺乳類ではシアル酸転移酵素スーパーファミリーに属する 20 種類の酵素が同定されている。これらのシアル酸転移酵素は、 形成するシアロ糖鎖の結合様式の違いによって、以下の 4 つ のファミリーに分けられる： $\beta$ - ガラクトシド $\alpha 2,3-$ シアル酸転 移酵素 (ST3Gal-I-VI)、 $\beta$ - ガラクトシド $\alpha 2,6$ - シアル酸転移酵素 (ST6Gal-I, -II)、GalNAca2,6- シアル酸転移酵素 (ST6GalNAc-IVI)、 $\alpha 2,8$ - シアル酸転移酵素 (ST8Sia-I-VI)。各シアル酸転移酵 素は哺乳類の複雑な生体システムにおいて、それぞれ固有の 役割をもつ。この総説では、最近の研究によって明らかになっ た哺乳類シアル酸転移酵素の機能多様性について述べ、哺乳 類が 20 種類のシアル酸転移酵素を必要とした理由を考察した い。

A. はじめに

シアル酸 $(\mathrm{Sias})^{*}$ は、負電荷を有する酸性糖であるノイラ ミン酸の誘導体である。これまでに 40 種類以上のシアル酸種 が自然界に見出されて抢り(1)、代表的なものとして、N-ア セチルノイラミン酸 (NeuAc)* $N$ - グリコリルノイラミン酸 (NeuGc)、デアミノノイラミン酸 $(\mathrm{KDN})$ が挙げられる。シアル 酸は非常に重要な分子であり、その生合成系が機能しなくな るとマウスでは胎生致死となる (2)。シアル酸は通常、糖鎖構 造の末端に存在している。シアル酸はその負電荷と細胞表面 分子上の暴露環境に広く存在していることから、細胞間相互 作用、細胞移動、接着、転移、病原体感染といった様々な生 命現象に関わる糖鎖構造の重要な決定因子として機能してい

Abbreviations: Sia, sialic acid; NeuAc, $N$-acetylneuraminic acid; CMP-Sia, cytidine 5'-monophospho-sialic acid; Glc, glucose; GlcNAc, $\mathrm{N}$-acetylglucosamine; Gal, galactose; GalNAc, $N$-acetylgalactosamine; Cer, ceramide; ER, endoplasmic reticulum.

*In this review, sialic acids in glycan structures are expressed as "Sias". But when Sia is limited to N-acetylneuraminic acid, "NeuAc" is used for "Sia". 
Table. Substrate specificities of mammlian sialyltransferases.

\begin{tabular}{|c|c|c|}
\hline Enzyme & Substrate carrier & Structures of representative substrates \\
\hline $\begin{array}{l}\text { ST3Gal-I } \\
\text { ST3Gal-II }\end{array}$ & $\begin{array}{l}\mathrm{O}-\mathrm{GP}>\mathrm{GL} \\
\mathrm{GL}>\mathrm{O}-\mathrm{GP}\end{array}$ & $\begin{array}{l}\text { Gal } \beta 1,3 \mathrm{GalNAc}^{-} \\
\text {Gal } \beta 1,3 \mathrm{GalNAc}-\text {, GalNAc } \beta 1,3 \mathrm{Gal}^{-}\end{array}$ \\
\hline $\begin{array}{l}\text { ST3Gal-III } \\
\text { ST3Gal-IV } \\
\text { ST3Gal-VI } \\
\text { ST3Gal-V }\end{array}$ & $\begin{array}{l}\mathrm{GP} \\
\mathrm{GP}>\mathrm{GL} \\
\mathrm{GP}, \mathrm{GL} \\
\mathrm{GL}\end{array}$ & $\begin{array}{l}\text { Gal } \beta 1,3 \mathrm{GlcNAc}->\text { Gal } \beta 1,4 \mathrm{GlcNAc}- \\
\text { Gal } \beta 1,4 \mathrm{GlcNAc}^{-}>\text {Gal } \beta 1,3 \mathrm{GlcNAc}- \\
\text { Gal } \beta 1,4 \mathrm{GlcNAc}^{-} \\
\text {Gal } \beta 1,4 \mathrm{Glc} \beta 1-\text { Cer, Gal } \beta 1-\mathrm{Cer}\end{array}$ \\
\hline $\begin{array}{l}\text { ST6Gal-I } \\
\text { ST6Gal-II }\end{array}$ & $\begin{array}{l}\text { N-GP, OL, GL } \\
\text { N-GP, OL }\end{array}$ & $\begin{array}{l}\text { Gal } \beta 1,4 \mathrm{GlcNAc}- \\
\text { GalNAc } \beta 1,4 \mathrm{GlcNAc}^{-}>\text {Gal } \beta 1,4 \mathrm{GlcNAc}^{-}\end{array}$ \\
\hline $\begin{array}{l}\text { ST6GalNAc-I } \\
\text { ST6GalNAc-II }\end{array}$ & $\begin{array}{l}\text { O-GP } \\
\text { O-GP }\end{array}$ & $\begin{array}{l}\text { GalNAc-, Gal } \beta 1,3 \text { GalNAc-, Sia } 22,3 \mathrm{Gal} \beta 1,3 \text { GalNAc- } \\
\text { GalNAc-, Gal } \beta 1,3 \text { GalNAc-, Sia } \alpha 2,3 \mathrm{Gal} \beta 1,3 \text { GalNAc- }\end{array}$ \\
\hline $\begin{array}{l}\text { ST6GalNAc-III } \\
\text { ST6GalNAc-IV } \\
\text { ST6GalNAc-V } \\
\text { ST6GalNAc-VI }\end{array}$ & $\begin{array}{l}\text { O-GP, GL } \\
\text { O-GP, OL > GL } \\
\text { GL } \\
\text { GL }>\text { GP }\end{array}$ & 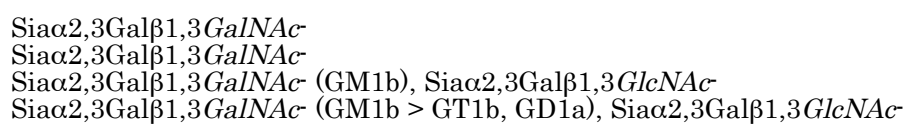 \\
\hline $\begin{array}{l}\text { ST8Sia-I } \\
\text { ST8Sia-V } \\
\text { ST8Sia-VI }\end{array}$ & $\begin{array}{l}\text { GL } \\
\text { GL } \\
\text { O-GP, OL }\end{array}$ & 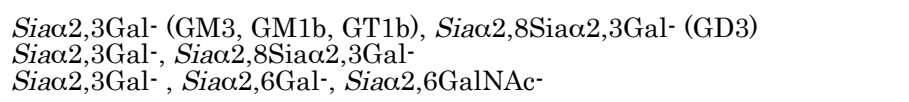 \\
\hline $\begin{array}{l}\text { ST8Sia-II } \\
\text { ST8Sia-IV } \\
\text { ST8Sia-III }\end{array}$ & $\begin{array}{l}\text { GP } \\
\text { GP } \\
\text { GP, GL }\end{array}$ & 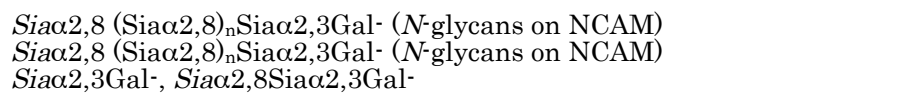 \\
\hline
\end{tabular}

GL, glycolipids; GP, glycoproteins; N-GP, $N$-glycosylated proteins; O-GP, $O$-glycosylated proteins; OL, oligosaccharides Sialic acid is transferred to the italicized sugar residue.

processes including cell-cell interaction, cell migration, adhesion, metastasis, and pathogen infection. In fact, there are numerous sialic acid recognition molecules such as the sialic acid-binding immunoglobulin-like lectins (siglecs) (3). A superfamily of glycosyltransferases called sialyltransferases catalyzes the synthesis of sialylglycoconjugates by transferring a sialic acid molecule from the donor substrate CMP-Sia to an acceptor carbohydrate. To date, cDNA cloning of 20 mammalian sialyltransferases has been completed, and their enzymatic properties have been analyzed. These enzymes are grouped into 4 families according to the type of carbohydrate linkage they synthesize (Table): $\beta$-galactoside $\alpha 2,3$-sialyltransferases (ST3Gal-I-VI), $\beta$-galactoside $\alpha 2,6$ sialyltransferases (ST6Gal-I and -II), $N$-acetylgalactosamine (GalNAc) $\alpha 2,6$-sialyltransferases (ST6GalNAc-I-VI), and $\alpha 2,8$-sialyltransferases (ST8Sia-I-VI) (4-7). This review describes the functional diversity of sialyltransferases on the basis of recent studies and discusses the necessity for the expression of as many as 20 different sialyltransferases in mammals.

\section{B. Structure of Sialyltransferases}

We will first describe the structural features of sialyltransferases. All sialyltransferases characterized in animals to date, ranging from insects to mammals, feature a type II transmembrane topology and usually localize to the Golgi apparatus. These sialyltransferases share common structural features, including a short $N$-terminal cytoplasmic tail, a transmembrane domain, a stem region, and a catalytic
ることがよくある。実際、自然界にはSiglec (3) に代表される シアル酸認識分子が多数存在する。シアル酸含有糖鎖の合成 においては、シアル酸転移酵素とよばれる糖転移酵素のスー パーファミリーが、ドナー基質である CMP-シアル酸から受 容糖鎖にシアル酸を転移する反応を触媒している。現在まで に、哺乳類のシアル酸転移酵素については 20 種類のメンバー の cDNA クローニングが完了しており、その酵素学的諸性質 の解析が行われてきている。これらの酵素は形成するシアロ 糖鎖の結合様式の違いによって、 $\beta$ - ガラクトシド $\alpha 2,3-$ シアル 酸転移酵素 (ST3Gal-I-VI)、 $\beta$ - ガラクトシド $\alpha 2,6$ - シアル酸転 移酵素 (ST6Gal-I, -II)、N-アセチルガラクトサミン (GalNAc) $\alpha 2,6$ - シアル酸転移酵素 (ST6GalNAc-I-VI)、 $\alpha 2,8$ - シアル酸転移 酵素 (ST8Sia-I-VI) の 4 つのファミリーに分類されている (4-7) (表)。本稿では、最近の研究によって明らかになった哺乳類 シアル酸転移酵素の機能多様性について述べ、哺乳類が 20 種 類のシアル酸転移酵素を必要とした理由を考察したい。

\section{B. シアル酸転移酵素の構造}

まず、シアル酸転移酵素の構造的特徵について説明する。 現在までに解析されている昆虫から哺乳類に至るすべての動 物由来シアル酸転移酵素はタイプII の膜タンパク質であり、 通常はゴルジ体に局在している。これらのシアル酸転移酵素 は共通の構造的特徵を有しており、 $\mathrm{N}$ 末端側の短い細胞質領 域、膜貫通ドメイン、ステム領域、触媒ドメインから構成さ れている（図 1)。アミノ酸鎖長は約 300 から 600 であるが、 


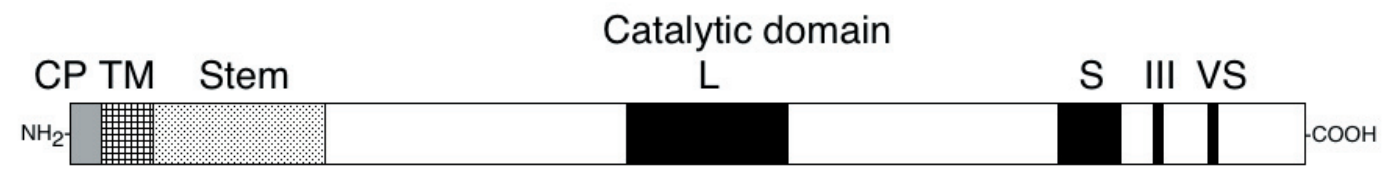

Fig. 1. Structure of animal sialyltransferase. CP, cytoplasmic tail; TM, transmembrane domain; Stem, stem region; L, sialyl motif L; S, sialyl motif S; III, sialyl motif III; VS, sialyl motif VS.

domain (Fig. 1). The amino acid sequence length of these enzymes ranges from about 300 to 600 residues. This range can primarily be attributed to differences in the length of the stem regions. Some sialyltransferases are cleaved within this region by a Golgi-resident protease and are secreted outside the cell $(8$, 9). The catalytic domain of animal sialyltransferases contains highly conserved motifs termed sialyl motifs L (long), S (short), III (third position in the sequence), and VS (very short) (10-14). Sialyl motif $\mathrm{L}$ is characterized by a $45-60$ amino acid region in the center of the protein, and it has been found to play a role in the binding of the donor substrate CMP-Sia (10). Sialyl motif $\mathrm{S}$ is located in the $\mathrm{C}$-terminal region and consists of a 20-30 amino acid stretch; it appears to be involved in the binding of both the donor and acceptor substrates (11). Sialyl motif III is located between sialyl motifs $\mathrm{S}$ and VS and has the consensus sequence of $(\mathrm{H} / \mathrm{y}) \mathrm{Y}(\mathrm{Y} / \mathrm{F} / \mathrm{W} / \mathrm{h})(\mathrm{E} / \mathrm{D} / \mathrm{q} / \mathrm{g})(12)$; this motif is involved in the catalytic activity of the enzyme. Sialyl motif VS is located in the C-terminal region and is characterized by 1 glutamic acid residue that is separated from a highly conserved histidine residue by 4 amino acid residues (13). This motif is also involved in the catalytic activity (15). In addition to the conventional sialyl motifs, family- and subfamily-specific sequence motifs have been proposed $(7,16)$. Recently, the crystal structure of porcine $\beta$-galactoside $\alpha 2,3$-sialyltransferase ST3Gal-I was revealed; this model stereo-chemically demonstrates the importance of sialyl motifs, especially the highly conserved histidine residue in the sialyl motif VS that serves as the catalytic base (17). The structure of porcine ST3Gal-I consists of a mixed $\alpha \beta$ fold that is composed of 7 twisted $\beta$-strands flanked by 12 $\alpha$-helices. In general, glycosyltransferases are structurally divided into 2 groups called GT-A and GT-B that feature 1 and 2 Rossman-like domains, respectively (18). Although porcine ST3Gal-I has a single Rossman domain, it shows sufficient differences in topology from other GT-A members to be classified as a member of a distinct separate subclass of GT-A termed GT-A (variant 2); bacterial sialyltransferases belong to another subclass of GT-A termed GT-A (variant 1) (17). Most glycosyltransferases use diphosphate nucleotide sugars as a donor substrate, but sialyltransferases use the monophosphate nucleotide sugar CMP-Sia as a donor substrate. This provides further evidence for the topological uniqueness of sialyltransferase.
その違いは主にステム領域長の違いにある。シアル酸転移酵 素の中にはゴルジ局在性のプロテアーゼによってステム領域 が切断され、細胞外に分泌されるものもある $(8,9)$ 。動物由来 シアル酸転移酵素の触媒ドメインには、シアリルモチーフ L (long)、S (short)、III（配列上 3 番目の位置)、VS (very short) とよばれる高度に保存されたモチーフがある(10-14)。シアリ ルモチーフ L は、一次構造上タンパク質の中央部分に位置す る45-60アミノ酸によって特徴づけられる領域で、ドナー基

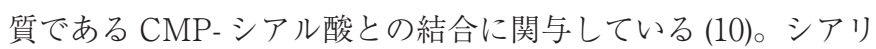
ルモチーフ S は C 末端領域に位置する 20-30アミノ酸からな る領域で、この領域はドナー基質とアクセプター糖鎖の両方 の結合に関与している(11)。シアリルモチーフ III はシアリル モチーフ S と VS の間に位置し、(H/y) Y $(\mathrm{Y} / \mathrm{F} / \mathrm{W} / \mathrm{h})(\mathrm{E} / \mathrm{D} / \mathrm{q} / \mathrm{g})$ というコンセンサス配列をもつ(12)。このモチーフは触媒活 性に関与している。シアリルモチーフVS は C 末端領域にあ り、高度に保存されたヒスチジン残基と、そこから 4 アミノ 酸隔てた位置にグルタミン酸が見いだされるというモチーフ である (13)。このモチーフも触媒活性に関与している (15)。こ ういった従来からのシアリルモチーフに加え、ファミリーお よびサブファミリー特異的な配列モチーフも提唱されている $(7,16)$ 。最近、ブタの $\beta$ - ガラクトシド $\alpha 2,3$ - シアル酸転移酵素 ST3Gal-I の結晶構造が決定されたが、シアリルモチーフの重 要性、特に触媒塩基として機能しているシアリルモチーフVS 中の高度に保存されたヒスチジンの重要性が立体化学的に示 された (17)。ブタ ST3Gal-I は 12 個の $\alpha$-ヘリックスと 7 個の $\beta$ - ストランドからなる $\alpha \beta$ 混成の折りたたみ構造をもつ。一般

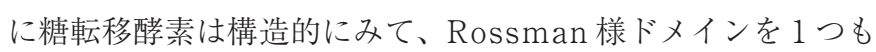

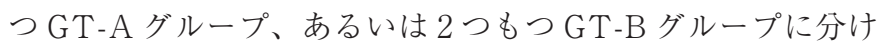
られる(18)。ブタ ST3Gal-I は Rossman ドメインを1つもつが、 他の GT-A メンバーとはトポロジーが大きく異なっているた め、GT-A グループの中でも GT-A (variant 2) と名づけた別の サブクラスに分類されている。細菌由来のシアル酸転移酵素 もまたGT-A (variant 1) と名づけた別のサブクラスに属する (17)。多くの糖転移醖素は二リン酸型糖ヌクレオチドをドナー 基質にしているが、シアル酸転移酵素は一リン酸型糖又クレ オチドである CMP - シアル酸をドナー基質にしている。この ことはシアル酸転移酵素がトポロジー的にユニークであると いう証拠の一つといえよう。 


\section{Functions of the ST3Gal Family Members}

The members of the ST3Gal family transfer sialic acid from CMP-Sia to the terminal galactose residues of glycans through an $\alpha 2,3$-linkage. To date, 6 members of the ST3Gal family have been identified in mammals. These members can be classified into 2 subfamilies according to amino acid sequence similarities, substrate specificities, and gene structures $(6,7,19)$. The first subfamily consists of 2 members, ST3Gal-I and -II, which preferentially utilize the Gal $\beta 1,3 \mathrm{GalNAc}$ structure on $O$-glycans of glycoproteins (core1 $O$-glycans) and glycolipids as acceptor substrates, respectively (20-22). Analysis of ST3Gal-I knockout mice showed that this enzyme plays an important role in the immune system. ST3Gal-I is involved in the sialylation of core1 $O$-glycans such as CD43 in T lymphocytes (23-27), and inactivation of ST3Gal-I leads to loss of $\mathrm{CD} 8^{+} \mathrm{T}$ cells by apoptosis $(23,24)$. CD8, which exists as a homodimer of $\mathrm{CD} 8 \alpha$ or a heterodimer of $\mathrm{CD} 8 \alpha$ and $\mathrm{CD} 8 \beta$, is critical for the development and activation of $\mathrm{T}$ cells that recognize antigenderived peptides bound to major histocompatibility complex class I molecules (MHCI). Both CD8 $\alpha$ and $\mathrm{CD} 8 \beta$ subunits are tethered to the thymocyte surface by their stalk region. Sialylation of $O$-glycans by ST3Gal-I on the stalk of CD8 $\beta$ has been shown to modulate the strength of $\mathrm{CD} 8 \alpha \beta$-MHCI binding $(26,27)$, although the converse has been reported as well (28). In addition to the involvement of ST3Gal-I in the immune system, it has been thought that this enzyme is highly related to tumorigenesis in bladder and breast cancers $(29,30)$. Substrate preference of ST3Gal-II analyzed in

\section{ST3Gal ファミリー酵素の役割}

ST3Gal ファミリーに属する酵素は、CMP - シアル酸をド ナー基質としてシアル酸を糖鎖末端のガラクトースに $\mathrm{a} 2,3$ の 結合様式で転移する。哺乳類では、ST3Gal ファミリーに属す る酵素は今までに 6 種類同定されている。アミノ酸配列の類似 性、基質特異性、遺伝子構造から、これらの酵素は 2 つのサ ブファミリーに分けることができる $(6,7,19)$ 。まず1つ目のサ ブファミリーは、糖タンパク質の $O$ - 結合型糖鎖 (コア 1 型 $O$ 結合型糖鎖)、および糖脂質中に見いだされる Galp1,3GalNAc 構造を好んで受容糖鎖基質にしている ST3Gal-I と -II の 2 つの 酵素からなる (20-22)。ST3Gal-I ノックアウトマウスの解析に より、この酵素は免疫系に扮いて重要な役割を担っているこ とが明らかになった。ST3Gal-I は Tリンパ球の CD43などに あるコア 1 型 $O$ - 結合型糖鎖 のシアリル化に関わっており (23 -27)、ST3Gal-I の不活化はアポトーシスによる $\mathrm{CD}^{+} \mathrm{T}$ 細胞の 䘫失をまねく $(23,24) 。 C D 8$ は、CD8 $\alpha$ のホモダイマー、ある いは CD $8 \alpha$ と CD $8 \beta$ のへテロダイマーとして存在しているが、 これは主要組織適合性複合体 $(\mathrm{MHC})$ クラス I 分子に結合した 抗原由来ペプチドを認識する $\mathrm{T}$ 細胞の発生と活性化に重要な 分子である。CD $8 \alpha$ 抢よび $\mathrm{CD} 8 \beta$ の両サブユニットは、それら がもつストーク領域を介して胸腺細胞表面に繋留されている。 ST3Gal-I によるCD8ßのストーク領域上にある $O$ - 結合型糖鎖 のシアリル化が、CD $8 \alpha \beta$ と MHCクラスI分子の結合の強さ を調節していることが示されているが(26,27)、それを否定し ている報告もある (28)。ST3Gal-I の免疫系への関わりに加え、 この酵素は膀胱がんや乳がんにおける腫瘍形成に深く関わっ ていると考えられている $(29,30)$ 。

In vitroで解析された ST3Gal-II の基質嗜好性によれ

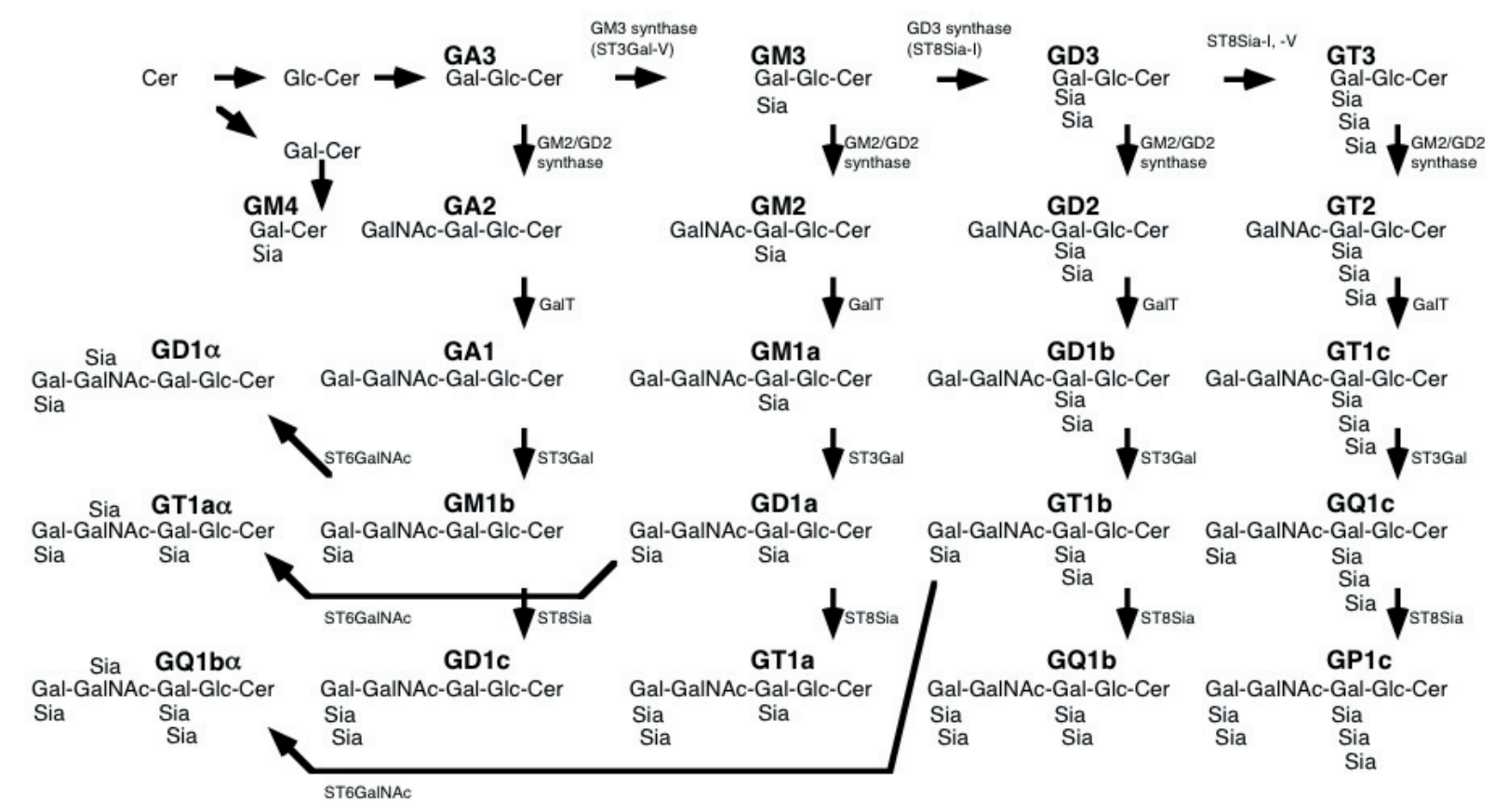

Fig. 2. Postulated pathway for ganglioside biosynthesis. Glc, glucose; Gal, galactose; GalNAc, $\mathrm{N}$-acetylgalactosamine; Sia, sialic acid; Cer, ceramide; GalT, galactosyltransferase. 
vitro suggests that this enzyme prefers glycolipids to glycoproteins (20-22). ST3Gal-II mRNA knockdown by short hairpin RNA causes a significant decrease in the expression of the sialic acid-containing glycosphingolipid ganglioside GD1a (31) (Fig. 2) in human mesenchymal stem cells and suppresses the differentiation of these cells into osteoblasts (32). It has further been proposed that GD1a is primarily synthesized by ST3Gal-II rather than ST3Gal-I in castration-resistant prostate cancer cells such as PC3 and DU145 (33). In addition to the Gal $\beta 1,3$ GalNAc structure, ST3Gal-II can utilize oligosaccharides containing the terminal GalNAc $\beta 1,3 \mathrm{Gal}$ determinant as acceptor substrates and synthesize NeuAc $\alpha 2,3$ GalNAc linkages (34), suggesting that ST3Gal-II may be involved in the biosynthesis of rare $\alpha 2,3$-sialylated globosides such as NeuAc $\alpha 2,3$ GalNAc $\beta 1,3$ Gal $\alpha 1,4$ Gal $\beta 1,3$ Glc $\beta 1$-Cer $(35,36)$.

Mouse ST3Gal-II is expressed in the immature heart but not in the adult heart. The generation of transgenic mice (4C30 line) overexpressing ST3Gal-II showed that prolonged expression of ST3Gal-II results in adult-onset cardiac dilatation in mice. These mice are potential new animal models for cardiac dilatation diseases such as dilated cardiomyopathy (37).

The other subfamily consists of 4 membersST3Gal-III, -IV, -V, and -VI. ST3Gal-III and -IV utilize both Gal $\beta 1,3 \mathrm{GlcNAc}$ and Gal $\beta 1,4 \mathrm{GlcNAc}$ structures predominantly on glycoproteins and oligosaccharides as acceptor substrates. However, their substrate preferences differ: ST3Gal-III prefers the Gal $\beta 1,3 \mathrm{GlcNAc}$ structure to the Gal $\beta 1,4 \mathrm{GlcNAc}$ structure, while ST3Gal-IV prefers Gal $\beta 1,4 \mathrm{GlcNAc}$ to Gal $\beta 1,3 \mathrm{GlcNAc}$ $(22,38)$. Human ST3Gal-IV exhibits significant activity toward glycolipids, but not ST3Gal-III (39). These enzymes are involved in the biosynthesis of the tumor-associated carbohydrate antigens sialyl-Lewis A (Sia $\alpha 2,3 \mathrm{Gal} \beta 1,3$ (Fuc $\alpha 1,4)$ GlcNAc-) and sialyl-Lewis X (Sia $2,3 \mathrm{Gal} \beta 1,4$ (Fuc $\alpha 1$, 3)GlcNAc-) $(40,41)$. These carbohydrate determinants are thought to play an important role in tumor progression through their involvement in adhesion, migration, and metastasis of cancer cells. Sialyl-Lewis epitopes are also known as the core carbohydrate structures of the ligands for the calciumdependent lectin selectin family, and they participate in leukocyte rolling in inflamed venules. Analysis of ST3GalIV knockout mice showed that this enzyme is involved in the selectin ligand formation $(42,43)$.

Asialoglycoproteins in plasma are eliminated by a clearance mechanism mediated by the Ashwell-Morell receptor of hepatocytes, originally termed the hepatic asialoglycoprotein receptor. ST3Gal-IV deficiency promotes asialoglycoprotein clearance mechanisms with a reduction in the plasma levels of the hemostasis-related sialoglycoprotein von Willebrand factor and platelets, which are endogenous
ば、この酵素は糖タンパク質よりも糖脂質を基質として好む ことが示唆されている(20-22)。ヒ卜間葉系幹細胞における ショートヘアピン RNAによるST3Gal-IIのノックダウン実 験では、シアル酸含有スフィンゴ糖脂質であるガングリオシ ド GDla (31) ( 図 2)の発現が著しく低下するとともに、骨芽 細胞への分化が抑制された (32)。PC3 や DU145 といった去勢 抵抗性前立腺がん細胞に扔いても、GD1aは㧍もにST3Gal-I よりも ST3Gal-IIによって合成されていると考えられてい る(33)。ST3Gal-II はGali1,3GalNAc 構造に加え、末端に GalNAc $\beta 1,3 \mathrm{Gal}$ 構造をもつオリゴ糖も受容糖鎖基質として利 用することができ、NeuAca2,3GalNAc 構造を形成する (34)。 このことから、ST3Gal-II は $\alpha 2,3$ - 結合でシアリル化された NeuAc $\alpha 2,3 \mathrm{GalNAc} \beta 1,3 \mathrm{Gal} \alpha 1,4 \mathrm{Gal} \beta 1,3 \mathrm{Glc} \beta 1-\mathrm{Cer}$ のような稀少 グロボシドの合成に関与している可能性がある $(35,36) 。$

ST3Gal-II はマウスでは発生期の心臟には発現している が、成体の心臟には発現していない。ST3Gal-II を過剩発現し ているトランスジェニックマウス (4C30 ライン)の解析により、 この酵素を継続的に発現させると成体では心臓肥大症が発症 することが明らかになった。このマウスは拡張型心筋症のよ うな心臟肥大を伴う疾患の新たなモデル動物となる可能性が ある (37)。

2つ目のサブファミリーには ST3Gal-III, -IV, -V, - VI の 4つの酵素が属している。ST3Gal-III と-IVは、拈もに糖夕 ンパク質やオリゴ糖上にある Gal $11,3 \mathrm{GlcNAc}$ 構造、拈よび Gal 1 1,4GlcNAc 構造を受容糖鎖基質にしている。しかし両者 の嗜好は異なり、ST3Gal-III は Gal $11,4 \mathrm{GlcNAc}$ 構造よりも Galp1,3GlcNAc 構造を好み、ST3Gal-IV はその逆である $(22$, 38)。ヒト ST3Gal-IV は糖脂質に対してもある程度の活性を示 すが、ST3Gal-III は示さない (39)。これらの酵素は腫瘍関連糖

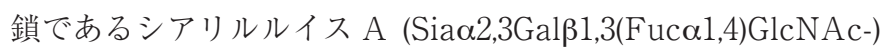

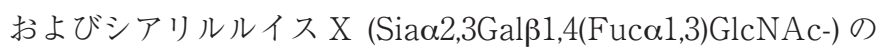
生合成に関与している $(40,41)$ 。これらの糖鎖はがん細胞の接 着、移動、転移などに関係して、がんの進行に重要な役割を 果たしていると考えられている。シアリルルイスエピトープ はカルシウム依存性レクチンであるセレクチンファミリーの リガンド糖鎖のコア構造としても知られており、炎症性細静 脈に打ける白血球のローリングに関与している。ST3Gal-IV ノックアウトマウスの解析では、この酵素がセレクチンリガ ンドの形成に関わっていることが示された $(42,43)$ 。

血漿中では、シアル酸がはずれた糖鎖をもつアシアロ糖 タンパク質は、元々はアシアロ糖タンパク質受容体とよばれ た肝細胞にある Ashwell-Morell 受容体が介するクリアランス 機構によって除去される。ST3Gal-IVの欠損では、アシアロ 糖タンパク質の除去が促進され、止血に関わるシアロ糖タン パク質フォンビルブランド因子と血小板の血漿内レベルが低

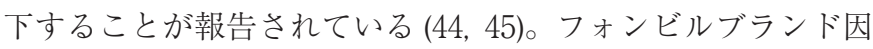
子と血小板は Ashwell-Morell 受容体の内在性リガンドであり、 
ligands of the Ashwell-Morell receptor, and causes prolonged bleeding and coagulation $(44,45)$.

ST3Gal-V is a known synthase of the ganglioside GM3 (46-49), but this enzyme also has ganglioside GM4 synthase activity (50) (Fig. 2). The genomic structure of the ST3Gal-V gene is rather simple compared to those of other members of this subfamily $(6,7,19)$, and substrate specificity of ST3Gal-V is also somewhat different from those of other members of this subfamily. Therefore, it may be better to further subdivide this subfamily into 2 groups-ST3Gal-V and other members.

GM3 is thought to be one of the key molecules of signal transduction in mammalian cells and is involved in a variety of biological processes, including insulin signaling (51-53), differentiation (54), and cell migration (55). ST3Gal-V knockout mice show increased insulin sensitivity because of an enhanced insulin receptor phosphorylation in skeletal muscles (51). These mice are protected from insulin resistance, induced by high-fat diet, indicating that GM3 is a negative regulator of insulin signaling.

ST3Gal-V knockout mice also exhibit complete hearing loss due to the functional disorganization of the organ of Corti in the inner ear, corroborating the importance of gangliosides, especially GM3, in the development and maintenance of hearing function (56).

In humans, it has been reported that an infantileonset symptomatic epilepsy syndrome associated with developmental stagnation and blindness found in Old Order Amish pedigree is caused by a homozygous loss-of-function mutation of GM3 synthase (57).

There are 3 isoforms of mouse ST3Gal-V, and the longest isoform, which has an arginine-based endoplasmic reticulum (ER)-targeting motif (RRXXXXR) in its cytoplasmic tail, is exclusively localized to the ER (58). Nonetheless, there seems to be little, if any, CMP-Sia in the ER, because the CMP-Sia transporter is predominantly localized to the medial- to trans-Golgi network (59). If this isoform cannot act as a GM3 synthase in the ER, the significance of the ER-localized isoform remains unclear. However, this isoform might exhibit a different function in the ER, for example chaperone activity.

ST3Gal-VI mainly utilizes the Gal $\beta 1,4 \mathrm{GlcNAc}$ structure on glycoproteins and glycolipids as an acceptor substrate (60). In some cell lines, this enzyme is thought to be involved in the synthesis of gangliosides such as sialylparagloboside ( $\mathrm{Sia} \alpha 2,3 \mathrm{Gal} \beta 1,4 \mathrm{GlcNAc} \beta 1,3$ Gal $\beta 1,4 \mathrm{Glc} \beta 1$-Cer) (33) and the sialyl-Lewis $\mathrm{X}$ epitope on glycoproteins such as MUC1 (61).

\section{Functions of the ST6Gal Family Members}

The members of the ST6Gal family were originally defined as enzymes that transfer sialic acid from CMP-Sia to
ST3Gal-IV 久損によるそれらの減少は出血および擬固時間の延 長を引き起こす。

ST3Gal-V はガングリオシド GM3 の合成酵素として知ら れているが(46-49)、ガングリオシド GM4 の合成活性も有する (50)（図 2)。ST3Gal-V 遺伝子のゲノム構造はこのサブファミ リーの他のメンバーのものよりかなり単純であり $(6,7,19)$ 、基 質特異性も他のメンバーとは若干異なる。それゆえ、このサ ブファミリーはST3Gal-V とそれ以外のメンバーの 2 つのグ ループにさらに細分したほうがよいのかもしれない。

GM3 は哺乳動物細胞に㧍けるシグナル伝達の鍵分子の一 つであると考元られており、インスリンシグナリング (51-53)、 分化 (54)、細胞移動 (55) といった様々な生命現象に関わってい る。ST3Gal-V ノックアウトマウスは、骨格筋に扔けるインス リン受容体のリン酸化の立進によってインスリン高感受性を 示した (51)。このマウスは高脂肪食によって誘導されるインス リン抵抗性（インスリンの利きが悪い状態）の影響をうけず、 GM3 がインスリンシグナリングの負の制御因子であることが 示された。

またST3Gal-Vノックアウトマウスは、内耳にあるコルチ 器の機能障害によって耳が完全に聞こえなくなっており、聴 覚機能の発達と維持におけるガングリオシド、特に GM3 の重 要性が示された (56)。

ヒトの場合、オールド・オーダー・アーミッシュ家系の人々 に見いだされる、発育不全と失明との関連がある小児期発症 性症候性てんかんは、GM3 合成酵素の木モ接合性機能衰失変 異によって引き起こされることが報告されている (57)。

マウス ST3Gal-Vには3つのアイソフォームがあり、アル ギニンに基づく小胞体 (ER) 移行モチーフ (RRXXXXR) を細胞 質領域にもつ最も長いアイソフォームは、専ら ER に局在する (58)。しかし、CMP-Sia 輸送体は主にメディアル－トランスゴ ルジに局在しているので (59)、ER には CMP-Sia はほとんど存 在しないと思われる。従って、ER 局在性のアイソフォームが ER でGM3 合成酵素として機能していないのであれば、この アイソフォームの存在意義は不明である。しかし、このアイ ソフォームは、シャペロン活性のような別の機能を ER で発揮 しているのかもしれない。

ST3Gal-VIは、糖タンパク質と糖脂質上にある GalB1,4GlcNAc 構造を扔もに受容糖鎖基質にしている (60)。い くつかの細胞に抢いては、この酵素はシアリルパラグロボシ ド (Sia $2,3 \mathrm{Gal} \beta 1,4 \mathrm{GlcNAc} \beta 1,3 \mathrm{Gal} \beta 1,4 \mathrm{Glc} \beta 1-\mathrm{Cer})$ といったガン グリオシドや (33)、MUC1のような糖タンパク質上のシアリ ルルイスXエピトープの合成に関与していると考えられてい る (61)。

\section{ST6Gal ファミリー酵素の役割}

ST6Gal ファミリーに属する酵素は、元々は CMP- シアル 酸からシアル酸を糖鎖末端のガラクトースに $\alpha 2,6$ の結合様式 
the terminal galactose residues of glycans through an $\alpha 2,6-$ linkage. To date, 2 members of the ST6Gal family, ST6Gal-I and -II, have been identified in mammals (62-69). These enzymes commonly utilize the Gal $\beta 1,4 \mathrm{GlcNAc}$ structure on glycoproteins and oligosaccharides as an acceptor substrate. ST6Gal-I is also thought to be involved in the biosynthesis of $\alpha 2,6$-sialylated glycolipids (70). The ST6Gal-I gene is ubiquitously expressed, whereas the ST6Gal-II gene is expressed in a tissue- and developmental stage-specific manner (67-69). The $\alpha 2,6$-sialylation to the terminal galactose by these enzymes, especially ST6Gal-I, is thought to inhibit signaling by galectins, which are $\beta$-galactoside-binding lectins that regulate diverse cellular processes, including adhesion, migration, proliferation and apoptosis (71).

ST6Gal-I knockout mice exhibit a severe immunosuppression phenotype with reduced serum immunoglobulin M (IgM) levels, impaired B cell proliferation in response to B cell surface IgM and CD40 crosslinking, attenuated antibody production by immunization with $\mathrm{T}$ cellindependent and $\mathrm{T}$ cell-dependent antigens, and induction of IgM antigen receptor endocytosis $(72,73)$. These findings indicate that ST6Gal-I plays an important role in the immune system.

It has been known that the expression of hepatic ST6Gal-I increases during the acute phase response in inflammation. ST6Gal-I deficiency in mice, especially lack of ST6Gal-I generated by a liver-specific promoter, is associated with severe neutrophilic and eosinophilic inflammation $(74,75)$. These results tightly link ST6Gal-I function to the regulation of inflammation.

Up regulation of ST6Gal-I has further been reported in multiple cancers, and high ST6Gal-I levels are associated with metastasis, poor prognosis, and the self-protection of tumors against apoptosis (76-79).

It is known that ST6Gal-I is cleaved at the stem region by the Golgi-resident protease $\beta$-site amyloid precursor protein-cleaving enzyme-1 (BACE1), and is secreted outside the cell as a soluble protein (8). BACE1 was originally identified as an enzyme that produces amyloid $\beta$-peptide, a pathogen of Alzheimer disease. This soluble form of ST6Gal-I is thought to be involved in the sialylation of soluble glycoprotein substrates (80) and myelopoiesis (81).

Enzymatic assays of ST6Gal-II indicated that this enzyme utilizes the LacdiNAc structure (GalNAc $\beta 1,4 \mathrm{GlcNAc}$ ) as a preferred acceptor substrate over the Gal $\beta 1,4 \mathrm{GlcNAc}$ structure $(82,83)$. When primary cultures of bovine mammary epithelial cells were stimulated with the pro-inflammatory cytokine interleukin-6, expression of the ST6Gal-II gene was up regulated (84). This suggests that the bovine ST6GalII gene may be involved in the inflammatory response. The human and mouse ST6Gal-II genes are mainly expressed
で転移する酵素として定義された。ST6Gal ファミリーに属す る酵素は、今までに哺乳類ではST6Gal-I と-II の 2 種類が同定 されている(62-69)。これらの酵素はともに糖タンパク質およ びオリゴ糖上にある Gal $1,4 \mathrm{GlcN}$ Ac 構造を受容糖鎖基質にし ている。またST6Gal-I は、 $\alpha 2,6$ - 結合したシアル酸をもつ糖脂 質の合成にも関与していると考えられている (70)。ST6Gal-I 遺 伝子は普遍的に発現しているが、ST6Gal-II 遺伝子は組織およ び発生過程特異的に発現している(67-69)。これらの酵素、特 にST6Gal-I による末端ガラクトースへの $\alpha 2,6$ 結合によるシア リル化は、接着、移動、増殖、アポトーシスといった様々な 細胞の挙動を制御している $\beta$-ガラクトシド結合性レクチンの ガレクチンによるシグナリングを阻害すると考えられている (71)。

ST6Gal-I ノックアウトマウスは、血清中の免疫グロブリ ン $\mathrm{M}(\mathrm{Ig} \mathrm{M})$ レベルの低下、B 細胞表面の IgM、CD40 を架橋 して活性化したときの $\mathrm{B}$ 細胞増殖の低下、 $\mathrm{T}$ 細胞非依存性 拉よび $\mathrm{T}$ 細胞依存性抗原による免疫化での抗体産生能の低 下、IgM 抗原受容体のエンドサイトーシスの惹起、といった 重篤な免疫抑制の表現型を示した $(72,73)$ これらのことは ST6Gal-I が免疫系に扔いて重要な役割を担っていることを示 している。

炎症に扔ける急性期反応では、肝臓の ST6Gal-I 発現量が 増加することが知られている。マウスではST6Gal-I、特に肝 臓特異的プロモーターによって産生される ST6Gal-I の欠損と、 重篤な好中球性炎症や好酸球性炎症との間には密接な関連性

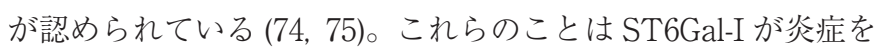
制御する際にも重要な役割を果たしていることを示している。

また、様々ながんでST6Gal-I の発現上昇が報告されてい る。ST6Gal-I の高発現レベルは、がん転移、予後不良、アポトー シスに対するがんの自己防衛などと関係がある (76-79)。

ST6Gal-I は、ゴルジ体局在性プロテアーゼ BACE1に よってステム領域で切断され、可溶性タンパク質として細胞 外に分泌されることが知られている(8)。BACE1 は、元々は アルツハイマー病の原因分子の 1 つであるアミロイド $\beta$ ペプ チドを産生する酵素として同定された。この可溶性タイプの ST6Gal-I は、可溶性糖タンパク質基質へのシアル酸転移や (80)、 骨髄造血に関わっていると考えられている $(81) 。$

ST6Gal-II の酵素学的解析によれば、この酵 素はGalß1,4GlcNAc 構造よりも LacdiNAc 構造 (GalNAc $\beta 1,4 \mathrm{GlcNAc)}$ をよりよい受容糖鎖基質としている $(82$, 83)。ウシ乳腺上皮細胞の初代培養を炎症誘発性サイトカイン であるインターロイキン -6 で刺激すると、ST6Gal-II 遺伝子の 発現上昇が認められた(83)。ウシ ST6Gal-II は炎症反応におい て重要な役割を担っているのかもしれない。ヒトとマウスの 
in the brain, suggesting that this enzyme plays a role in the nervous system $(67,68,84)$. Pharmacogenetic analysis of the response to the schizophrenia drug risperidone suggested an association of the ST6Gal-II gene with this disease (85).

\section{E. Functions of the ST6GalNAc Family Members}

The members of the ST6GalNAc family transfer sialic acid from CMP-Sia to the $N$-acetylgalactosamine residues of glycans through an $\alpha 2,6$-linkage. To date, 6 members of the ST6GalNAc family have been identified in mammals. These members can be classified into 2 subfamilies according to amino acid sequence similarities, substrate specificities, and gene structures $(6,7,19)$. ST6GalNAc-I and -II constitute the 2 members of the first subfamily. They exhibit similar substrate specificity, utilizing mainly GalNAc, Gal $\beta 1,3$ GalNAc, and Sia $\alpha 2,3$ Gal $\beta 1,3$ GalNAc structures on the $O$-glycans of glycoproteins as acceptor substrates (86-92). ST6GalNAc-I is thought to be responsible for the synthesis of the tumor-associated sialyl-Tn antigen (Sia $2,6 \mathrm{GalNAc}-$ $O$-Ser/Thr) (87, 93-95), whereas ST6GalNAc-II mediates the synthesis of the sialyl-Tn antigen on IgA1 in IgA nephropathy (91).

The other subfamily consists of 4 members ST6GalNAc-III, -IV, -V, and -VI (94-103). ST6GalNAc-III, -IV, -V, and -VI commonly utilize the Sia $2,3 \mathrm{Gal} \beta 1,3 \mathrm{GalNAc}$ structure as an acceptor substrate. However, their substrate preferences differ: mouse ST6GalNAc-III and -IV, but not mouse ST6GalNAc-V or -VI, can efficiently utilize fetuin, which contains Sia $\alpha 2,3 \mathrm{Gal} \beta 1,3 \mathrm{GalNAc-}$ $O$-glycans, as an acceptor substrate (97, 101-103). However, human ST6GalNAc-VI can utilize fetuin as an acceptor substrate (105). The oligosaccharide NeuAc $\alpha 2,3 \mathrm{Gal} \beta 1,3 \mathrm{GalNAc}$ is a preferred substrate for ST6GalNAc-IV, but not for ST6GalNAc-III $(97,99)$. The ganglioside GM1b is a preferred substrate for ST6GalNAcIII, -V, and -VI, but not for ST6GalNAc-IV (96-99, 101 -103) (Fig. 2). ST6GalNAc-VI also exhibits significant levels of activity toward the gangliosides GT1b and GD1a (103). In addition, ST6GalNAc-V and -VI exhibit activity toward sialyllactotetraosylceramide (sialyl Lc4, NeuAc $\alpha 2,3$ Gal $\beta 1,3$ GlcNAc $\beta 1,3$ Gal $\beta 1,4$ Glc $\beta 1$-Cer), which does not contain the Sia $\alpha 2,3 \mathrm{Gal} \beta 1,3 \mathrm{GalNAc}$ structure (104). ST6GalNAc-III and -VI can generate the disialylgalactosylgloboside NeuAc $\alpha 2,3 \mathrm{Gal} \beta 1,3(\mathrm{NeuAc} \alpha 2,6)$ GalNAc $\beta 1,3$ Gal $\alpha 1,4$ Gal $\beta 1,4$ Glc $\beta 1$-Cer from monosialylgalactosylgloboside in vitro, and expression profiles of these enzymes suggest that ST6GalNAc-VI is involved in the synthesis of disialylgalactosylgloboside in the kidney (105).

The expression patterns of these enzymes also differ: expression of ST6GalNAc-III, -IV, and -VI is observed in many tissues, but ST6GalNAc-V is exclusively expressed
ST6Gal-II 遺伝子はおもに脳で発現しており、神経系での役割 が示唆される $(67,68,84)$ 。統合失調症治療薬であるリスペリド ンに対する反応についてのゲノム薬理学的解析では、ST6GalII 遺伝子と統合失調症との関連性が示唆されている (85)。

\section{E. ST6GalNAc ファミリー酵素の役割}

ST6GalNAc ファミリーに属する酵素は、CMP - シアル酸 からシアル酸を糖鎖中の $N$ - アセチルガラクトサミンに $\alpha 2,6$ の 結合様式で転移する。哺乳類では、ST6GalNAc ファミリーに 属する酵素は今までに 6 種類同定されている。アミノ酸配列の 類似性、基質特異性、遺伝子構造から、これらの酵素は 2 つ

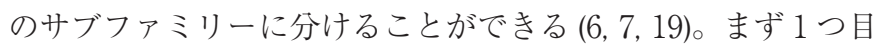
のサブファミリーは、ST6GalNAc-I と -II の 2つの酵素からな る。これらの酵素は類似した基質特異性をもち、おもに糖夕 ンパク質の $O$ - 結合型糖鎖上にある GalNAc、GalB1,3GalNAc、 Sia $\alpha 2,3 \mathrm{Gal} \beta 1,3 \mathrm{GalNAc}$ 構造を受容糖鎖基質にしている (8692)。ST6GalNAc-I は、がんと関わりの梁いシアリル Tn 抗原 (Siaa2,6GalNAc-O-Ser/Thr) の生成に関与していると考えられ ている (87，93-95)。一方 ST6GalNAc-II は、IgA 腎症に拀いて $\operatorname{Ig} \mathrm{A} 1$ 上にシアリル Tn 抗原を発現させるのに関わっていると 考えられている (91)。

もう 1 つのサブファミリーにはST6GalNAc-III, -IV, -V, -VI の 4 つの酵素が属している (94-103)。ST6GalNAc-III, -IV, -V, -VI は Sia $22,3 \mathrm{Gal} \beta 1,3 \mathrm{G}$ alNAc 構造を共通して受容糖鎖基 質にしている。しかし、各酵素の基質の嘹好は異なる：マウ ス ST6GalNAc-III と-IV は、Sia 2 2,3Gal 11,3 GalNAc- $O$ - 結合型 糖鎖をもつフェツインを受容糖鎖基質として効率よく使うこ とができるが(97)、マウス ST6GalNAc-VやVIは基質にでき ない(101-103)。しかし、ヒト ST6GalNAc-VIはフェッイン を基質にできる(105)。オリゴ糖の NeuAc $\alpha 2,3 \mathrm{Gal} \beta 1,3 \mathrm{GalNAc}$ はST6GalNAc-IV のよい基質であるが、ST6GalNAc-IIIに

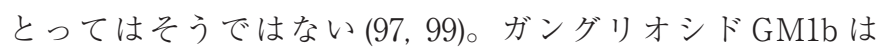
ST6GalNAc-III, -V, -VI のよい基質であるが、ST6GalNAc-IV にとってはそうではない (96-99, 101-103)（図 2)。ST6GalNAcVI はガングリオシド GT1b, GDla に対しても有意の活性を示

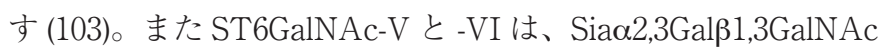
構造をもたないシアリルラクトテトラオシルセラミド (sialyl Lc4, NeuAc $\alpha 2,3 \mathrm{Gal} \beta 1,3 \mathrm{GlcNAc} \beta 1,3 \mathrm{Gal} \beta 1,4 \mathrm{Glc} \beta 1$-Cer) に対して も活性を示す (104)。ST6GalNAc-III と-VIは、in vitro の反応 においてモノシアリルガラクトシルグロボシドからジシアリ

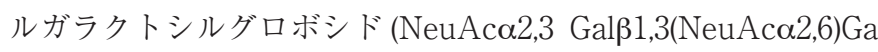

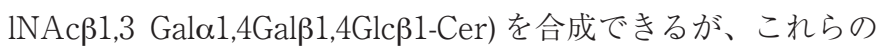
酵素の発現様式を考慮すると、腎臓ではST6GalNAc-VI がジ シアリルガラクトシルグロボシドを合成していると思われる (105)。

各酵素の発現パターンも異なる：ST6GalNAc-III, -IV, -VI は多くの組織で発現しているが、ST6GalNAc-V の発現は脳 
in the brain $(101,102)$. However, when ST6GalNAc-V is expressed in breast cancer cells, it mediates brain metastasis (106). The expression of ST6GalNAc-V in breast cancer cells enhances their adhesion to brain endothelial cells and their passage across the blood-brain barrier. On the other hand, when ST6GalNAc-V is overexpressed in glioma cells, it inhibits glioma growth in vivo, probably due to alternation of the cell-surface glycolipid composition (107). It has further been reported that the ST6GalNAc-V-overexpressing MDCK cells were capable of growing in shake flasks as suspension cultures unlike the parental adhesive MDCK cells, and they could be used as an efficient expression system of influenza virus (108).

Expression of ST6GalNAc-IV is induced in activated lymphocytes, suggesting its involvement in the early alternation of the sialylation pattern of cell surface molecules in these immune cells (98).

\section{F. Functions of the ST8Sia Family Members}

The members of the ST8Sia family transfer sialic acid from CMP-Sia to the terminal sialic acid residues of glycans through an $\alpha 2,8$-linkage. Six members of the ST8Sia family have been identified in mammals to date. These members can be classified into 2 or 3 subfamilies according to amino acid sequence similarities, substrate specificities, and gene structures $(6,7,19,109)$. The first subfamily consists of 3 members-ST8Sia-I, -V and -VI. ST8Sia-I is a known ganglioside GD3 synthase and utilizes GM3 as an acceptor substrate (Fig. 2). However, ST8Sia-I can also utilize GM1b, GD1a, GT1b, and GD3 as substrates to some extent (110, 111). GD3 is the starting molecule for the synthesis of band c-series gangliosides, many of which are thought to be critical in various biological processes including adhesion, toxin binding, neurite extension, cell growth, and apoptosis (112, 113). Overexpression of ST8Sia-I sensitizes Hep3B hepatocarcinoma cells to hypoxia and reduced tumor growth by suppressing the $\mathrm{c}-\mathrm{Src} / \mathrm{NF}-\kappa \mathrm{B}$ survival pathway (114). ST8Sia-I knockout mice, which lack all b- and c-series gangliosides, show an almost complete nervous tissue morphology with no apparent abnormal behavior (112). Nonetheless, they exhibit reduced regeneration of axotomized hypoglossal nerves as compared to wild-type mice. In addition, ST8Sia-I knockout mice exhibit increased sensory responses to thermal and mechanical stimuli and decreased responses during the late phase of the formalin injection test (115). This suggests that $b$ - and c-series gangliosides are critical in the repair and functional maintenance of the nervous system. Double knockout mice lacking both the GM2/GD2 synthase and GD3 synthase genes, and therefore expressing only the GM3 ganglioside, exhibit lethal audiogenic seizures (116). It has also been reported that double knockout mice
に限局している $(101,102)$ 。かし、ST6GalNAc-Vが乳が ん細胞で発現すると、脳への転移を促進する(106)。すなわ ちST6GalNAc-V の発現により、乳がん細胞の脳内皮細胞へ の接着が増強され、血液脳関門を通過しやすくなる。一方、 ST6GalNAc-V をグリオーマ細胞で強制発現させると、おそら く細胞表面糖脂質組成が変化することにより、神経膠腫の成 長が阻害される (107)。またST6GalNAc-V をMDCK 細胞で強 制発現させると、接着性の親株と違ってフラスコでの浮遊振 とう培養が可能になり、インフルエンザウイルスの効率よい 生産システムとして使えるようになったことが報告されてい る $(108)$ 。

ST6GalNAc-IV の発現は活性化されたリンパ球で誘導され る。これら免疫細胞の細胞表面分子がもつシアリル化パター ンは活性化初期に変化するが、これにST6GalNAc-IVが関与 していることが示唆される $(98)$ 。

\section{F. ST8Sia ファミリー酵素の役割}

ST8Siaファミリーに属する酵素は、CMP-シアル酸から シアル酸を糖鎖末端のシアル酸に $\alpha 2,8$ の結合様式で転移す る。哺乳類では、ST8Siaファミリーに属する酵素は今まで に6 種類同定されている。アミノ酸配列の類似性、基質特異 性、遺伝子構造から、これらの酵素は 2 つまたは 3 つのサブ

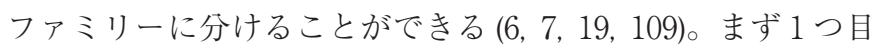
のサブファミリーは、ST8Sia-I, -V , -VIの 3 つの酵素からな る。ST8Sia-I はガングリオシドGD3の合成酵素として知られ、 GM3 を受容糖鎖基質にしている（図 2)。しかし、ST8Sia-I は GM1b, GD1a, GT1b, GD3 も基質としてある程度利用できる (110, 111)。b- およびc- 系列ガングリオシドは GD3 から作ら れるが、これらのガングリオシドの多くは、接着、毒素結合、 神経突起伸長、細胞増殖、アポトーシスといった様々な生命 現象において重要であると考えられている $(112,113)$ 。肝がん 細胞 Hep3B でST8Sia-I を強制発現させると、低酸素状態に感 受性になるとともに、C-Src/NF-кBによる生存経路を抑制し て腫瘍成長を抑える (114)。ST8Sia-I ノックアウトマウスは、 b-およびc- 系列ガングリオシドをすべて久失するが、神経組 織の形態はほとんど問題なく、明らかな異常行動も示さなかっ た (112)。しかし、野生型マウスにくらべると、軸索切断され た舌下神経の再生能が低下していた。またST8Sia-Iノックア ウトマウスは、温熱刺激や機械的刺激に対して鋭敏になると ともに、ホルマリン注入試験ではその後期過程において反応 性が鈍くなった (115)。これらより、b-抽びc-系列ガングリ オシドは、神経系の修復や機能維持にとって重要な働きをも つことが示唆される。GM2/GD2 合成酵素とGD3 合成酵素の 両方を欠失したダブルノックアウトマウスの場合、ガングリ 
exhibit the refractory skin injury phenotype (117). This supports the important roles of gangliosides in various biological processes.

ST8Sia-V is thought to be involved in the biosynthesis of gangliosides such as GD1c, GT1a, GQ1b, and GT3 (118, 119) (Fig. 2). In contrast to the other 2 members of this subfamily, ST8Sia-VI exhibits low activity toward glycolipids, but exhibits high activity toward $O$-glycans of glycoproteins and sialyloligosaccharides $(120,121)$. ST8Sia-V and VI are expressed in natural killer (NK) cells, suggesting that $\alpha 2,8$ disialic acid structures produced by these enzymes, which are ligands for Siglec-7, may be important in the regulation of the inhibitory function of Siglec-7 expressed on NK cells via a cis interaction (122).

The other subfamily consists of 3 members-ST8SiaII, -III, and -IV. ST8Sia-II and -IV can synthesize polysialic acid, the homopolymer of $\alpha 2,8$-linked sialic acid, on specific molecules $(123,124)$ such as neural cell adhesion molecule (NCAM). On the other hand, ST8Sia-III cannot synthesize polysialic acid on NCAM, although it can synthesize polysialic acid on the enzyme itself (autopolysialylation) (125). This subfamily can therefore be further subdivided into 2 groups-ST8Sia-II and -IV, and ST8Sia-III (109). Polysialic acid on NCAM plays an important role in cell adhesion; cell migration; brain development; neural regeneration; and plastic processes, including learning and memory (126-129). It also acts as a reservoir of neurotrophic factors (130). Although both ST8Sia-II and -IV are involved in the biosynthesis of polysialic acid, their enzymatic properties are somewhat different $(15,125,131)$. For example, ST8Sia-IV catalyzes longer polysialic acid chain formation of NCAM than ST8SiaII. It has been reported that their cooperative action on NCAM results in longer polysialic acid chain formation than that when the enzymes are used individually (132).

The expression of mouse ST8Sia-II in the brain is developmentally regulated, and it decreases drastically after birth (133), whereas the expression of mouse ST8Sia-IV continues in the adult brain (134). However, the expression of ST8Sia-II also continues in a confined region of the adult brain. In the cerebral cortex of adult mouse brain, ST8Sia-II is the major polysialic acid synthase in immature neurons of the paleocortex layer II and the hippocampal subgranular zone (135). In contrast, ST8Sia-IV is responsible for polysialic acid expression in mature interneurons and in most regions of cortical neuropil.

ST8Sia-II and -IV knockout mice show different phenotype with regard to synaptic plasticity, synaptic transmission, and behavior due to differences in the properties and expression patterns of polysialic acid synthesized by these enzymes (136-139). Double knockout mice of ST8SiaII and -IV exhibit severe neurodevelopmental defects (128,
オシドは GM3 しか発現していないが、このマウスは致死性の 聴原性発作を起こした (116)。さらにダブルノックアウトマウ スでは難治性皮膚傷害も報告されている(117)。このことは様々 な生命現象に㧍けるガングリオシドの重要性を示している。

ST8Sia-V は GD1c, GT1a, GQ1b, GT3 といったガングリオ シドの生合成に関与すると考えられている $(118,119)$ （図 2)。 一方、ST8Sia-VIは他の 2 つの酵素に比べ、糖脂質に対しては 低い活性しか示さないが、糖タンパク質の $O$ - 結合型糖鎖やシ アリルオリゴ糖に対して高い活性を示す $(120,121)$ 。ST8Sia-V と-VI はナチュラルキラー $(\mathrm{NK})$ 細胞で発現しているが、Siglec-7 のリガンドでもあるこれらの酵素が合成する $\alpha 2,8$ - ジシ アル酸構造は、NK 細胞上に発現している Siglec-7 がもつ抑制 性作用を cis による相互作用を介して調節するのに重要な役割 を果たしているのかもしれない (122)。

2つ目のサブファミリーには ST8Sia-II, -III, -IVの 3 つの 酵素が属している。ST8Sia-II と-IV は、 $\alpha 2,8$ - 結合をしたシア ル酸のホモポリマーであるポリシアル酸を神経細胞接着分子 (NCAM)のような特定の分子上に合成することができる $(123$, 124)。一方、ST8Sia-III は自己ポリシアリル化により自身の上 にポリシアル酸を合成することはできるが、NCAM 上には合 成できない (125)。従って、このサブファミリーはST8Sia-II, -IV と ST8Sia-III の 2 つの゙ループにさらに分けることができ る(109)。NCAM 上のポリシアル酸は、細胞接着、細胞移動、 脳の発生、神経再生、学習や記憶を含む可塑過程において重 要な役割を果たしている(126-129)。また神経栄養因子のリザー バーとしても機能する (130)。ST8Sia-II と IV の両酵素はポリ シアル酸の生合成に関与するものの、酵素学的諸性質には若 干の違いがある $(15,125,131)$ 。例えば、ST8Sia-IV は NCAM のポリシアル酸合成に関して ST8Sia-II より長めのものをつく る。また、NCAMに対して両酵素の協同的作用があると、そ れぞれの酵素を単独で作用させたときと比べて、より長いポ リシアル酸を合成できることが報告されている (132)。

マウスST8Sia-II の脳に扔ける発現は発生過程において制 御されて抢り、生後は劇的に減少する (133)。一方、ST8SiaIV の発現は成体脳においても継続している(134)。しかし、 ST8Sia-II の発現も成体脳の限局された部位においては継続し ている。マウス成体脳の大脳皮質では、ST8Sia-II は大脳旧皮 質二層と海馬顆粒細胞層下部の未成熟なニューロンに扔ける 主要なポリシアル酸合成酵素である (135)。対照的に、ST8SiaIV は成熟した介在ニューロンと皮質神経網の大部分における ポリシアル酸発現を担っている。

ST8Sia-II と-IVのノックアウトマウスでは、各酵素が合 成するポリシアル酸の性質や発現様式の違いにより、シナプ ス可塑性、シナプス伝達、行動などにおいて異なった表現型 が示されている(136-139)。また ST8Sia-II と-IV のダブルノッ クアウトマウスは重篤な神経発生障害を示している $(128,140$, 141)。ヒトの場合、一塩基多型により E147K 変異をもった 
$140,141)$. In humans, structurally and functionally impaired polysialic acid synthesized by ST8Sia-II with an E141K mutation caused by a single nucleotide polymorphism seems to be associated with schizophrenia (142).

ST8Sia-III utilizes the Sia 2,3Gal structure on both glycoproteins such as adipo Q and CD166 and glycolipids as an acceptor substrate $(133,143-145)$, but glycoproteins are preferred substrates over glycolipids. ST8Sia-III is thought to be involved in the synthesis of the $\alpha 2,8$-triSia units on glycoproteins in the developing mouse brain (146).

\section{G. Concluding Remarks}

As described above, it has been convincingly demonstrated that mammalian sialyltransferases are involved in various biological processes. It seems that for simply transferring a sialic acid to the terminal position of glycans, a few sialyltransferases with broad substrate specificity could suffice. However, mammals express as many as 20 sialyltransferases with different (but partly overlapping) substrate specificity. Mammals have developed complicated body systems, such as the immune system, the nervous system, and the homeostasis-maintenance system. Because the negative charge of sialic acid plays an important role in molecular interactions, the utilization of sialic acid is thought to be highly associated with the development of these complicated systems. The fine-tuning of these systems requires many functional glycans with different structures. The addition of sialic acid to the terminal position of glycans through multiple linkage specificities gives diversity to glycan structures and functions. In fact, Sia $2,3 \mathrm{Gal}$ and $\mathrm{Sia} \alpha 2,6 \mathrm{Gal}$ residues are structurally and functionally different, because the phenotype of ST6Gal-I knockout mice cannot be compensated by ST3Gal enzymes and vice versa.

Efficiencies of substrate utilization of some sialyltransferases differ between glycoprotein and glycolipid carriers. Therefore, respective sialyltransferases with substrate preference specific for glycoproteins and glycolipids have been evolved. For the former, respective sialyltransferases with substrate preference specific for $N$-glycans and $O$-glycans have been further evolved. Consequently, mammals have developed as many as 20 sialyltransferases through gene duplication events $(6,7)$, each having specialized functions and substrate specificity for the fine-tuning of the expression of sialylglycoconjugates. Due to gene duplication events, some members of the same sialyltransferase subfamily share common substrate specificities. This redundancy is especially important when the function of one gene is impaired. In addition to expanding the number of sialyltransferase members, mammals have developed mechanisms of transcriptional regulation for each sialyltransferase gene $(7,147)$, resulting in a variety of developmental stage-
ST8Sia-IIによって合成された、構造的にも機能的にも異常な ポリシアル酸と統合失調症の間には関連性があるように思わ れる (142)。

ST8Sia-III は adipo Qや CD166 といった糖タンパク質や 糖脂質上の Sia $\alpha 2,3 \mathrm{Gal}$ 構造を受容糖鎖基質として利用する (133，143-145)。しかし、糖脂質より糖タンパク質を好むよう である。発生過程にあるマウス脳では、ST8Sia-III は糖タンパ

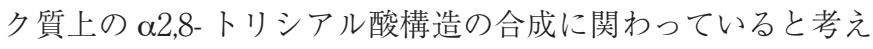
られている (146)。

\section{G. 結 語}

以上のように、哺乳類シアル酸転移酵素は非常に多岐にわ たる生命現象に関わっていることがわかってきた。糖鎖の末 端にシアル酸を結合させるだけなら、基質特異性の広いせい ぜい数種類のシアル酸転移酵素だけで十分だろう。しかし哺 乳類は、異なる基質特異性をもった 20 もの酵素（一部の酵素 では基質特異性が部分的に重なってはいるが）を発現してい る。哺乳類では免疫系、神経系、恒常性の維持などに関わる 複雑な生体システムを発達させてきた。シアル酸がもつ負電 荷は、分子間相互作用の場において重要な役割を果たすため、 こういったシステムの発達と、シアル酸の利用は密接に関連 していると思われる。このような複雑な生体システムをきめ 細かく制御するためには、構造の異なる多くの機能性糖鎖が 必要だと思われる。複数の結合特異性によってシアル酸を糖 鎖末端に付加することで、糖鎖の構造と機能に多様性が生ま れる。実際、ST6Gal-I ノックアウトマウスの表現型はST3Gal 酵素によって補償されず、またその逆も然りであることから、 Sia $2,3 \mathrm{Gal}$ 構造と Sia $2,6 \mathrm{Gal}$ 構造は、構造的にも機能的にも異 なっているといえる。

いくつかのシアル酸転移酵素では、糖鎖担体が糖タンパ ク質なのか糖脂質なのかで基質の利用効率が異なる。そこで、 糖タンパク質に特異的な酵素と糖脂質に特異的な酵素が進化 してきた。また糖タンパク質を好む酵素では、 $N$-結合型糖鎖 特異的な酵素、 $O$ - 結合型特異的な酵素がさらに進化してきた。 結果として、哺乳類はシアル酸含有糖鎖の発現を精微に制御 するために、それぞれ固有の機能と基質特異性をもった 20 も のシアル酸転移酵素を、遺伝子重複を介して発達させてきた $(6$, 7)。遺伝子重複のために、同じサブファミリーに属するシアル 酸転移酵素の中には共通の基質特異性をもつものもある。こ のような重複性は、1つの遺伝子が機能しないときに特に重要 である。シアル酸転移酵素のメンバーを増やすとともに、哺 乳類は各シアル酸転移酵素遺伝子の転写制御機構も発達させ てきており (7, 147)、その結果、発生過程や組織特異的な様々 なシアリル化様式が生まれた。実際、各シアル酸転移酵素遺 
and tissue-specific sialylation patterns. In fact, each sialyltransferase gene has its own expression pattern (148), and the expression of some sialyltransferases is regulated by multiple promoters. In order to tightly regulate the expression of sialylglycoconjugates involved in the complicated body systems, precise mechanisms for the transcriptional regulation of the sialyltransferase genes are required. As the details of such mechanisms remain unclear, we have to elucidate them in the future.

At present, the detailed physiological functions of some sialyltransferases are not yet fully understood. Further comprehensive analysis of these enzymes should help to elucidate the biological significance of each sialyltransferase and the sialylglycoconjugates they generate. It seems that generation and analysis of each sialyltransferase knockout mice will proceed in the future. However, to understand physiological roles of each sialyltransferase precisely, we have to analyze them carefully. There are several enzymes showing similar substrate specificity. So, when the expression of one sialyltransferase is artificially suppressed, another sialyltransferase may ectopically express to compensate for the function of the suppressed sialyltransferase. Is such function of another sialyltransferase really physiological? To get precise information, it would be necessary to take much time in exploring sialyltransferase knockout mice, including generation and analysis of conditional knockout mice or double knockout mice. Another problem to be solved is the identification of physiological substrates of each sialyltransferase. So far, substrate specificities of each sialyltransferase have been determined on the basis of in vitro enzymatic characterization. However, it remains uncertain what substrates each sialyltransferase uses and what products they generate under physiological conditions in many cases. To elucidate actual physiological functions of each sialyltransferase, it would be necessary to identify their physiological substrates and products carefully. The function of splicing variants that lack enzymatic activity is also interesting and is to be solved in the future. Such information should be useful to develop methods to effectively utilize sialyltransferases and sialylglycoconjugates in the prevention and treatment of numerous diseases.
伝子には固有の発現様式があり (148)、その中には複数のプロ モーターによる制御を受けているものもある。複雑な生体シ ステムを司るシアル酸含有糖鎖の発現を厳密に制御するため には、シアル酸転移酵素遺伝子の発現を正確に制御するしく みが必要なのだろう。そういったしくみの詳細はまだ不明の ままなので、我々は将来、それらを解明しなければならない。

現在、シアル酸転移酵素の中には詳細な生理機能が十分に 理解されていないものもある。それらの酵素機能を網羅的に 調べていくことは、各酵素や各シアル酸含有糖鎖の生物学的 重要性を解明する上で助けになるだろう。今後は、各シアル 酸転移酵素のノックアウトマウスの作製や解析が進むと思わ れる。しかし、各酵素の生理機能を正確に理解するためには、 注意深く解析する必要がある。類似した基質特異性をもつ酵 素が複数存在するので、一つのシアル酸転移酵素の発現を人 為的に抑制した場合、その酵素の機能を補うために別の酵素 が異所的に発現してくるかもしれない。このような酵素の機 能は、本当に生理的なものといえるのだろうか? 正確な情報 を得るためには、コンディショナルノックアウトマウスやダ ブルノックアウトマウスの作製、解析を含め、ノックアウト マウスの解析にもっと時間をかけることが必要になるだろう。 もう一つの解決するべき問題として、各シアル酸転移酵素の 生理的基質の同定があげられる。従来、各酵素の基質特異性 は in vitroにおける酵素解析に基づいて決定されてきた。しか し、生理的条件下において各酵素が何を基質とし、何を合成 しているのか、多くの場合わかっていない。各シアル酸転移 酵素の真の生理機能を明らかにするためには、生理的基質お よびその反応産物を注意深く同定していく必要がある。また、 酵素活性をもたないスプライシングバリアントの機能も興味 深く、この問題も将来は解決されねばならない。こういった 情報は、様々な病気の予防や治療において、シアル酸転移酵 素やシアル酸含有糖鎖をうまく活用しようとする際にも役立 つだろう。

\section{References}

1. Varki, A. (1992) Glycobiology 2, 25-40.

2. Schwarzkopf, M., Knobeloch, K. P., Rohde, E., Hinderlich, S., Wiechens, N., Lucka, L., Horak, I., Reutter, W., and Horstkorte, R. (2002) Proc. Natl. Acad. Sci. USA 99, 5267-5270.

3. Crocker, P. R., Paulson, J. C., and Varki, A. (2007) Nat. Rev. Immunol. 7, 255-266.

4. Tsuji, S., Datta, A. K., and Paulson, J. C. (1996) Glycobiology 6(7), v-vii.

5. Tsuji, S. (1996) J.Biochem. 120, 1-13.

6. Takashima, S. (2008) Biosci. Biotechnol. Biochem. 72, 1155-1167.

7. Harduin-Lepers, A. (2010) Glycobiol. Insights 2, 29-61.

8. Kitazume, S., Tachida, Y., Oka, R., Shirotani, K., Saido, T. C., and Hashimoto, Y. (2001) Proc. Natl. Acad. Sci. USA 98, 13554-13559.

9. El-Battari, A., Prorok, M., Angata, K., Mathieu, S., Zerfaoui, M., Ong, E., Suzuki, M., Lombardo, D., and Fukuda, M. (2003) Glycobiology 
13, 941-953.

10. Drickamer, K. (1993) Glycobiology 3, 2-3.

11. Livingston, B. D., and Paulson, J. C. (1993) J. Biol. Chem. 268, 11504-11507.

12. Jeanneau, C., Chazalet, V., Aug, C., Soumpasis, D. M., Harduin-Lepers, A., Delannoy, P., Imberty, A., and Breton, C. (2004) J. Biol. Chem. 279, 13461-13468.

13. Geremia, R. A., Harduin-Lepers, A., and Delannoy, P. (1997) Glycobiology 7(2), v-vii.

14. Datta, A. K. (2009) Curr. Drug Targets 10, 483-498.

15. Kitazume-Kawaguchi, S., Kabata, S., and Arita, M. (2001) J. Biol. Chem. 276, 15696-15703.

16. Patel, P. Y., and Balaji, P. V. (2006) Glycobiology 16, 108-116.

17. Rao, F. V., Rich, J. R., Rakiç B., Buddai, S., Schwartz, M. F., Johnson, K., Bowe, C., Wakarchuk, W. W., DeFrees, S., Withers, S. G., and Strynadka, N. C. J. (2009) Nat. Struct. Mol. Biol. 16, 1186-1188.

18. Lairson, L. L., Henrissat, B., Davies, G. J., and Withers, S. G. (2008) Annu. Rev. Biochem. 77, 521-555.

19. Harduin-Lepers, A., Mollicone, R., Delannoy, P., and Oriol, R. (2005) Glycobiology 15, 805-817.

20. Lee, Y.-C., Kurosawa, N., Hamamoto, T., Nakaoka, T., and Tsuji, S. (1993) Eur. J. Biochem. 216, 377-385.

21. Lee, Y.-C., Kojima, N., Wada, E., Kurosawa, N., Nakaoka, T., Hamamoto, T., and Tsuji, S. (1994) J. Biol. Chem. $269,10028-10033$.

22. Kono, M., Ohyama, Y., Lee, Y.-C., Hamamoto, T., Kojima, N., and Tsuji, S. (1997) Glycobiology 7, 469-479.

23. Priatel, J. J., Chui, D., Hiraoka, N., Simmons, C. J., Richardson, K. B., Page, D. M., Fukuda, M., Varki, N. M., and Marth, J. D. (2000) Immunity 12, 273-283.

24. Van Dyken S. J., Green, R. S., and Marth, J. D. (2007) Mol. Cell. Biol. 27, 1096-1111.

25. Martin, L. T., Marth, J. D., Varki, A., and Varki, N. M. (2002) J. Biol. Chem. 277, 32930-32938.

26. Moody, A. M., Chui, D., Reche, P. A., Priatel, J. J., Marth, J. D., and Reinherz, E. L. (2001) Cell 107, 501-512.

27. Moody, A. M., North, S. J., Reinhold, B., Van Dyken, S. J., Rogers, M. E., Panico, M., Dell, A., Morris, H. R., Marth, J. D., and Reinherz, E. L. (2003) J. Biol. Chem. 278, 7240-7246.

28. Kao, C., Sandau, M. M., Daniels, M. A., and Jameson, S. C. (2006) J. Immunol. 176, 7421-7430.

29. Videira, P. A., Correia, M., Malagolini, N., Crespo, H. J., Ligeiro, D., Calais, F. M., Trindade, H., and Dall'Olio, F. (2009) BMC Cancer 9, 357.

30. Picco, G., Julien, S., Brockhausen, I., Beatson, R., Antonopoulos, A., Haslam, S., Mandel, U., Dell, A., Pinder, S., Taylor-Papadimitriou, J., and Burchell, J. (2010) Glycobiology 20, 1241-1250.

31. Svennerholm, L. (1964) J. Lipid Res. 5, 145-155.

32. Yang, H. J., Jung, K. Y., Kwak, D. H., Lee, S. H., Ryu, J. S., Kim, J. S., Chang, K. T., Lee, J. W., and Choo, Y. K. (2011) Dev. Growth Differ. 53, 323-332.

33. Hatano, K., Miyamoto, Y., Nonomura, N., and Kaneda, Y. (2011) Int. J. Cancer 129, 1838-1847.

34. Toivonen, S., Aitio, O., and Renkonen, O. (2001) J. Biol. Chem. 276, 37141-37148.

35. Schwarting, G. A., Carroll, P. G., and DeWolf, W. C. (1983) Biochem. Biophys. Res. Commun. 112, 935-940.

36. Kundu, S. K., Harati, Y., and Misra, L. K. (1984) Biochem. Biophys. Res. Commun. 118, 82-89.

37. Suzuki, O., Kanai, T., Nishikawa, T., Yamamoto, Y., Noguchi, A., Takimoto, K., Koura, M., Noguchi, Y., Uchio-Yamada, K., Tsuji, S., and Matsuda, J. (2011) Proc. Jpn. Acad., Ser. B. in press.

38. Sasaki, K., Watanabe, E., Kawashima, K., Sekine, S., Dohi, T., Oshima, M., Hanai, N., Nishi, T., and Hasegawa, M. (1993) J. Biol. Chem. 268, 22782-22787.

39. Kitagawa, H., and Paulson, J. C. (1994) J. Biol. Chem. 269, 1394-1401.

40. Carvalho, A. S., Harduin-Lepers, A., Magalhães, A., Machado, E., Mendes, N., Costa, L. T., Matthiesen, R., Almeida, R., Costa, J., and Reis, C. A. (2010) Int. J. Biochem. Cell Biol. 42, 80-89.

41. Pérez-Garay, M., Arteta, B., Pagès, L., de Llorens, R., de Bolòs, C., Vidal-Vanaclocha, F., and Peracaula, R. (2010) PLoS One 5, e12524.

42. Ellies, L. G., Sperandio, M., Underhill, G. H., Yousif, J., Smith, M., Priatel, J. J., Kansas, G. S., Ley, K., and Marth, J. D. (2002) Blood 100, 3618-3625.

43. Sperandio, M., Frommhold, D., Babushkina, I., Ellies, L. G., Olson, T. S., Smith, M. L., Fritzsching, B., Pauly, E., Smith, D. F., Nobiling, R., Linderkamp, O., Marth, J. D., Ley, K. (2006) Eur. J. Immunol. 36, 3207-3215.

44. Ellies, L. G., Ditto, D., Levy, G. G., Wahrenbrock, M., Ginsburg, D., Varki, A., Le, D. T., and Marth, J. D. (2002) Proc. Natl. Acad. Sci. USA 99, 10042-10047.

45. Grewal, P. K., Uchiyama, S., Ditto, D., Varki, N., Le, D. T., Nizet, V., and Marth, J. D. (2008) Nat. Med. 14, $648-655$.

46. Ishii, A., Ohta, M., Watanabe, Y., Matsuda, K., Ishiyama, K., Sakoe, K., Nakamura, M., Inokuchi, J., Sanai, Y., and Saito, M. (1998) J. Biol. Chem. 273, 31652-31655.

47. Kono, M., Takashima, S., Liu, H., Inoue, M., Kojima, N., Lee, Y.-C., Hamamoto, T., and Tsuji, S. (1998) Biochem. Biophys. Res. Commun. 253, 170-175.

48. Fukumoto, S., Miyazaki, H., Goto, G., Urano, T., Furukawa, K., and Furukawa, K. (1999) J. Biol. Chem. 274, 9271-9276.

49. Kapitonov, D., Bieberich, E., and Yu, R. K. (1999) Glycoconj. J. 16, 337-350.

50. Chisada, S., Yoshimura, Y., Sakaguchi, K., Uemura, S., Go, S., Ikeda, K., Uchima, H., Matsunaga, N., Ogura, K., Tai, T., Okino, N., Taguchi, R., Inokuchi, J., and Ito, M. (2009) J. Biol. Chem. 284, 30534-30546.

51. Yamashita, T., Hashiramoto, A., Haluzik, M., Mizukami, H., Beck, S., Norton, A., Kono, M., Tsuji, S., Daniotti, J. L., Werth, N., Sandhoff, R., Sandhoff, K., and Proia, R. L. (2003) Proc. Natl. Acad. Sci. USA 100, 3445-3449.

52. Kabayama, K., Sato, T., Kitamura, F., Uemura, S., Kang, B. W., Igarashi, Y., and Inokuchi, J. (2005) Glycobiology 15, 21-29.

53. Kabayama, K., Sato, T., Saito, K., Loberto, N., Prinetti, A., Sonnino, S., Kinjo, M., Igarashi, Y., and Inokuchi, J. (2007) Proc. Natl. Acad. Sci. USA 104, 13678-13683.

54. Chung, T.-W., Choi, H.-J., Lee, Y.-C., and Kim, C.-H. (2005) Glycobiology 15, 233-244.

55. Hashiramoto, A., Mizukami, H., and Yamashita, T. (2006) Oncogene 25, 3948-3955.

56. Yoshikawa, M., Go, S., Takasaki, K., Kakazu, Y., Ohashi, M., Nagafuku, M., Kabayama, K., Sekimoto, J., Suzuki, S., Takaiwa, K., Kimit- 
suki, T., Matsumoto, N., Komune, S., Kamei, D., Saito, M., Fujiwara, M., Iwasaki, K., and Inokuchi, J. (2009) Proc. Natl. Acad. Sci. USA 106, 9483-9488.

57. Simpson, M. A., Cross, H., Proukakis, C., Priestman, D. A., Neville, D. C., Reinkensmeier, G., Wang, H., Wiznitzer, M., Gurtz, K., Verganelaki, A., Pryde, A., Patton, M. A., Dwek, R. A., Butters, T. D., Platt, F. M., and Crosby, A. H. (2004) Nat. Genet. 36, $1225-1229$.

58. Uemura, S., Yoshida, K., Shishido, F., and Inokuchi, J. (2009) Mol. Biol. Cell. 20, 3088-3100.

59. Zhao, W., Chen, T.-L., Vertel, B. M., and Colley, K. J. (2006) J. Biol. Chem. 281, 31106-31118.

60. Okajima, T., Fukumoto, S., Miyazaki, H., Ishida, H., Kiso, M., Furukawa, K., Urano, T., and Furukawa, K. (1999) J. Biol. Chem. 274, $11479-11486$.

61. Chachadi, V. B., Cheng, H., Klinkebiel, D., Christman, J. K., and Cheng, P. W. (2011) Int. J. Biochem. Cell Biol. 43, $586-593$.

62. Weinstein, J., Lee, E. U., McEntee, K., Lai, P.-H., and Paulson, J. C. (1987) J. Biol. Chem. 262, 17735-17743.

63. Hamamoto, T., Kawasaki, M., Kurosawa, N., Nakaoka, T., Lee, Y.-C., and Tsuji, S. (1993) Bioorg. Med. Chem. 1, 141-145.

64. Grundnann, V., Nerlich, C., Rein, T., and Zettlmeissl, G. (1990) Nucleic Acids Res. 18, 667.

65. Mercier, D., Wierinckx, A., Oulmouden, A., Gallet, P. F., Palcic, M. M., Harduin-Lepers, A., Delannoy, P., Petit, J. M., Levéziel, H., and Julien, R. (1999) Glycobiology 9, 851-863.

66. Takashima, S., Tsuji, S., and Tsujimoto, M. (2002) J. Biol. Chem. 277, 45719-45728.

67. Krzewinski-Recchi, M.-A., Julien, S., Juliant, S., Teintenier-Lelièvre, M., Samyn-Petit, B., Montiel, M.-D., Mir, A.-M., Cerutti, M., Harduin-Lepers, A., and Delannoy, P. (2003) Eur. J. Biochem. 270, 950-961.

68. Takashima, S., Tsuji, S., and Tsujimoto, M. (2003) J. Biochem. 134, 287-296.

69. Laporte, B., Gonzalez-Hilarion, S., Maftah, A., and Petit, J. M. (2009) Glycobiology 19, 1082-1093.

70. Korekane, H., Matsumoto, A., Ota, F., Hasegawa, T., Misonou, Y., Shida, K., Miyamoto, Y., and Taniguchi, N. (2010) J. Biochem. 148, 359 -370 .

71. Zhuo, Y., and Bellis, S. L. (2011) J. Biol. Chem. 286, 5935-5941.

72. Hennet, .T, Chui, D., Paulson, J. C., and Marth, J. D. (1998) Proc. Natl. Acad. Sci. USA 95, 4504-4509.

73. Grewal, P. K., Boton, M., Ramirez, K., Collins, B. E., Saito, A., Green, R. S., Ohtsubo, K., Chui, D., and Marth, J. D. (2006) Mol. Cell. Biol. 26, 4970-4981.

74. Nasirikenari, M., Segal, B. H., Ostberg, J. R., Urbasic, A., and Lau, J. T. (2006) Blood 108, 3397-3405.

75. Nasirikenari, M., Chandrasekaran, E. V., Matta, K. L., Segal, B. H., Bogner, P. N., Lugade, A. A., Thanavala, Y., Lee, J. J., and Lau, J. T. (2010) J. Leukoc. Biol. 87, 457-466.

76. Recchi, M. A., Hebbar, M., Hornez, L., Harduin-Lepers, A., Peyrat, J. P., and Delannoy, P. (1998) Cancer Res. 58, $4066-4070$.

77. Petretti, T., Kemmner, W., Schlze, B., and Schlag, P. M. (2000) Gut 46, 359-366.

78. Qian, J., Zhu, C.-H., Tang, S., Shen, A.-J., Ai, J., Li, J., Geng, M.-Y., and Ding, J. (2009) Acta Pharmacol. Sin. 30, $1039-1045$.

79. Swindall, A. F., and Bellis, S. L. (2011) J. Biol. Chem. 286, 22982-22990.

80. Sugimoto, I., Futakawa, S., Oka, R., Ogawa, K., Marth, J. D., Miyoshi, E., Taniguchi, N., Hashimoto, Y., and Kitazume, S. (2007) J. Biol. Chem. 282, 34896-34903.

81. Jones, M. B., Nasirikenari, M., Feng, Li., Migliore, M. T., Choi, K.-S., Kazim, L., and Lau, J. T. (2010) J. Biol. Chem. $285,25009-25017$.

82. Rohfritsch, P. F., Joosten, J. A., Krzewinski-Recchi, M. A., Harduin-Lepers, A., Laporte, B., Juliant, S., Cerutti, M., Delannoy, P., Vliegenthart, J. F., and Kamerling, J. P. (2006) Biochim. Biophys. Acta 1760, 685-692.

83. Laporte, B., Gonzales-Hilarion, S., Maftah, A., and Petit, J. M. (2009) Glycobiology 19, 1082-1093.

84. Lehoux, S., Groux-Degroote, S., Cazet, A., Dhaenens, C. M., Maurage, C. A., Caillet-Boudin, M. L., Delannoy, P., and Krzewinski-Recchi, M. A. (2010) Glycoconj. J. 27, 99-144.

85. Ikeda, M., Tomita, Y., Mouri, A., Koga, M., Okochi, T., Yoshimura, R., Yamanouchi, Y., Kinoshita, Y., Hashimoto, R., Williams, H. J., Takeda, M., Nakamura, J., Nabeshima, T., Owen, M. J., O’Donovan, M. C., Honda, H., Arinami, T., Ozaki, N., and Iwata, N. (2010) Biol. Psychiatry 67, 263-269.

86. Kurosawa, N., Takashima, S., Kono, M., Ikehara, Y., Inoue, M., Tachida, Y., Narimatsu, H., and Tsuji, S. (2000) J. Biochem. 127, $845-854$.

87. Ikehara, Y., Kojima, N., Kurosawa, N., Kudo, T., Kono, M., Nishihara, S., Issiki, S., Morozumi, K., Itzkowitz, S., Tsuda, T., Nishimura, S. I., Tsuji, S., and Narimatsu, H. (1999) Glycobiology 9, 1213-1224.

88. Kurosawa, N., Inoue, M., Yoshida, Y., and Tsuji, S. (1996) J. Biol. Chem. 271, 15109-15116.

89. Sotiropoulou, G., Kono, M., Anisowicz, A., Stenman, G., Tsuji, S., and Sager, R. (2002) Mol. Med. 8, $42-55$.

90. Kono, M., Tsuda, T., Ogata, S., Takashima, S., Liu, H., Hamamoto, T., Itzkowitz, S. H., Nishimura, S., and Tsuji, S. (2000) Biochem. Biophys. Res. Commun. 272, 94-97.

91. Raska, M., Moldoveanu, Z., Suzuki, H., Brown, R., Kulhavy, R., Andrasi, J., Hall, S., Vu, H. L., Carlsson, F., Lindahl, G., Tomana, M., Julian, B. A., Wyatt, R. J., Mestecky, J., and Novak, J. (2007) J. Mol. Biol. 369, 69-78.

92. Marcos, N. T., Pinho, S., Grandela, C., Cruz, A., Samyn-Petit, B., Harduin-Lepers, A., Almeida, R., Silva, F., Morais, V., Costa, J., Kihlberg, J., Clausen, H., and Reis, C. A. (2004) Cancer Res. 64, 7050-7057.

93. Julien, S., Krzewinski-Recchi, M. A., Harduin-Lepers, A., Gouyer, V., Huet, G., Le Bourhis, X., and Delannoy, P. (2001) Glycoconj. J. 18, 883-893.

94. Sewell, R., Bökström, M, Dalziel, M., Gscheissner, S., Karlsson, H., Noll, T., Gätgens, J., Clausen, H., Hansson, G. C., Burchell, J., and Taylor-Papadimitriou, J. (2006) J. Biol. Chem. 281, 3586-3594.

95. Marcos, N. T., Bennett, E. P., Gomes, J., Magalhaes, A., Gomes, C., David, L., Dar, I., Jeanneau, C., Defrees, S., Krustrup, D., Vogel, L. K., Kure, E. H., Burchell, J., Taylor-Papadimitriou, J., Clausen, H., Mandel, U., and Reis, C. A. (2011) Front. Biosci. 3, $1443-1455$.

96. Sjoberg, E. R., Kitagawa, H., Glushka, J., van Halbeek, H., and Paulson, J. C. (1996) J. Biol. Chem. 271, 7450-7459.

97. Lee, Y.-C., Kaufmann, M., Kitazume-Kawaguchi, S., Kono, M., Takashima, S., Kurosawa, N., Liu, H., Pircher, H., and Tsuji, S. (1999) J. Biol. Chem. 274, 11958-11967.

98. Kaufmann, M., Blaser, C., Takashima, S., Schwartz-Albiez, R., Tsuji, S., and Pircher, H. (1999) Int. Immunol. 11, $731-738$.

99. Harduin-Lepers, A., Stokes, D. C., Steelant, W. F., Samyn-Petit, B., Krzewinski-Recchi, M. A., Vallejo-Ruiz, V., Zanetta, J. P., Aug , C., and Delannoy, P. (2000) Biochem. J. 352, 37-48. 
100. Ko, H.-K., Song, K.-H., Jin, U.-H., Seong, H.-H., Chang, Y.-C., Kim, N.-H., Kim, D.-S., Lee, Y.-C., and Kim, C.-H. (2010) Glycoconj. J. 27, 367-374.

101. Okajima, T., Fukumoto, S., Ito, H., Kiso, M., Hirabayashi, Y., Urano, T., and Furukawa, K. (1999) J. Biol. Chem. $274,30557-30562$.

102. Ikehara, Y., Shimizu, N., Kono, M., Nishihara, S., Nakanishi, H., Kitamura, T., Narimatsu, H., Tsuji, S., and Tatematsu, M. (1999) FEBS Lett. 463, 92-96.

103. Okajima, T., Chen, H. H., Ito, H., Kiso, M., Tai, T., Furukawa, K., Urano, T., and Furukawa, K. (2000) J. Biol. Chem. 275 , 6717-6723.

104. Tsuchida, A., Okajima, T., Furukawa, K., Ando, T., Ishida, H., Yoshida, A., Nakamura, Y., Kannagi, R., Kiso, M., and Furukawa, K. (2003) J. Biol. Chem. 278, 22787-22794.

105. Senda, M., Ito, A., Tsuchida, A., Hagiwara, T., Kaneda, T., Nakamura, Y., Kasama, K., Kiso, M., Yoshikawa, K., Katagiri, Y., Ono, Y., Ogiso, M., Urano, T., Furukawa, K., Oshima, S., and Furukawa, K. (2007) Biochem. J. 402, 459-470.

106. Bos, P. D., Zhang, X. H., Nadal, C., Shu, W., Gomis, R. R., Nguyen, D. X., Minn, A. J., van de Vijver, M. J., Gerald, W. L., Foekens, J. A., and Massagu , J. (2009) Nature 459, 1005-1009.

107. Kroes, R. A., He, H., Emmett, M. R., Nilsson, C. L., Leach, F. E. 3rd, Amster, I. J., Marshall, A. G., and Moskal, J. R. (2010) Proc. Natl. Acad. Sci. USA 107, 12646-12651.

108. Chu, C., Lugovtsev, V., Golding, H., Betenbaugh, M., and Shiloach, J. (2009) Proc. Natl. Acad. Sci. USA 106, $14802-14807$.

109. Harduin-Lepers, A., Petit, D., Mollicone, R., Delannoy, P., Petit, J. M., and Oriol, R. (2008) BMC Evol. Biol. 8, 258.

110. Nara, K., Watanabe, Y., Kawashima, I., Tai, T., Nagai, Y., and Sanai, Y. (1996) Eur. J. Biochem. 238, $647-652$.

111. Nakayama, J., Fukuda, M. N., Hirabayashi, Y., Kanamori, A., Sasaki, K., Nishi, T., and Fukuda, M. (1996) J. Biol. Chem. 271, $3684-$ 3691.

112. Okada, M., Itoh, M., Haraguchi, M., Okajima, T., Inoue, M., Oishi, H., Matsuda, Y., Iwamoto, T., Kawano, T., Fukumoto, S., Miyazaki, H., Furukawa, K., Aizawa, S., and Furukawa, K. (2002) J. Biol. Chem. 277, 1633-1636.

113. Bhunia, A. K., Schwarzmann, G., and Chatterjee, S. (2002) J. Biol. Chem. 277, 16396-16402.

114. Lluis, J. M., Llacuna, L., von Montfort, C., B rcena, C., Enrich, C., Morales, A., and Fernandez-Checa, J. C. (2009) PLoS One 4, e8059.

115. Handa, Y., Ozaki, N., Honda, T., Furukawa, K., Tomita, Y., Inoue, M., Furukawa, K., Okada, M., and Sugiura, Y. (2005) Pain 117, 271279.

116. Kawai, H., Allende, M. L., Wada, R., Kono, M., Sango, K., Deng, C., Miyakawa, T., Crawley, J. N., Werth, N., Bierfreund, U., Sandhoff, K., and Proia, R. L. (2001) J. Biol. Chem. 276, 6885-6888.

117. Inoue, M., Fujii, Y., Furukawa, K., Okada, M., Okumura, K., Hayakawa, T., Furukawa, K., and Sugiura, Y. (2002) J. Biol. Chem. 277, 29881-29888.

118. Kono, M., Yoshida, Y., Kojima, N., and Tsuji, S. (1996) J. Biol. Chem. 271, 29366-29371.

119. Kim, Y.-J., Kim, K.-S., Do, S.-I., Kim, C.-H., Kim, S.-K., and Lee, Y.-C. (1997) Biochem. Biophys. Res. Commun. 235, 327-330.

120. Takashima, S., Ishida, H.-k., Inazu, T., Ando, T., Ishida, H., Kiso, M., Tsuji, S., and Tsujimoto, M. (2002) J. Biol. Chem. 277, 2403024038.

121. Teintenier-Lelievre M, Julien S, Juliant S, Guerardel Y, Duonor-Cérutti M, Delannoy P, and Harduin-Lepers A. (2005) Biochem. J. 392, $665-674$.

122. Avril, T., North, S. J., Haslam, S. M., Willison, H. J., and Crocker, P. R. (2006) J. Leukoc. Biol. 80, 787-796.

123. Zuber, C., Lackie, P. M., Catterall, W. A., and Roth, J. (1992) J. Biol. Chem. 267, 9965-9971.

124. Yabe, U., Sato, C., Matsuda, T., and Kitajima, K. (2003) J. Biol. Chem. 278, 13875-13880.

125. Angata, K., Suzuki, M., McAuliffe, J., Ding, Y., Hindsgaul, O., and Fukuda, M. (2000) J. Biol. Chem. 275, $18594-18601$.

126. Hildebrandt, H., Mühlenhoff, M., Weinhold, B., and Gerardy-Schahn, R. (2007) J. Neurochem. 103 Suppl. 1, $56-64$.

127. Bork, K., Gagiannis, D., Orthmann, A., Weidemann, W., Kontou, M., Reutter, W., and Horstkorte, R. (2007) J. Neurochem. 103 Suppl. 1, 65-71.

128. Angata, K., Huckaby, V., Ranscht, B., Terskikh, A., Marth, J. D., and Fukuda, M. (2007) Mol. Cell. Biol. 27, $6659-6668$.

129. Mühlenhoff, M., Oltmann-Norden, I., Weinhold, B., Hildebrandt, H., and Gerardy-Schahn, R. (2009) Biol. Chem. 390, $567-574$.

130. Kanato, Y., Kitajima, K., and Sato, C. (2008) Glycobiology 18, 1044-1053.

131. Angata, K., Suzuki, M., and Fukuda, M. (1998) J. Biol. Chem. 273, 28524-28532.

132. Angata, K., Suzuki, M., and Fukuda, M. (2002) J. Biol. Chem. 277, 36808-36817.

133. Yoshida, Y., Kojima, N., Kurosawa, N., Hamamoto, T., and Tsuji, S. (1995) J. Biol. Chem. 270, 14628-14633.

134. Yoshida, Y., Kojima, N., and Tsuji, S. (1995) J. Biochem. 118, 658-664.

135. Nacher, J., Guirado, R., Varea, E., Alonso-Llosa, G., Röckle, I., and Hildebrandt, H. (2010) Neuroscience 167, $825-837$.

136. Eckhardt, M., Bukalo, O., Chazal, G., Wang, L., Goridis, C., Schachner, M., Gerardy-Schahn, R., Cremer, H., and Dityatev, A. (2000) J. Neurosci. 20, 5234-5244.

137. Angata, K., Long, J. M., Bukalo, O., Lee, W., Dityatev, A., Wynshaw-Boris, A., Schachner, M., Fukuda, M. (2004) J. Biol. Chem. 279, 32603-32613.

138. Stoenica, L., Senkov, O., Gerardy-Schahn, R., Weinhold, B., Schachner, M., and Dityatev, A. (2006) Eur. J. Neurosci. 23, $2255-2264$.

139. Calandreau, L., M rquez, C., Bisaz, R., Fantin, M., and Sandi, C. (2010) Genes Brain Behav. 9, 958-967.

140. Weinhold, B., Seidenfaden, R., Röckle, I., Mühlenhoff, M., Schertzinger, F., Conzelmann, S., Marth, J. D., Gerardy-Schahn, R., and Hildebrandt, H. (2005) J. Biol. Chem. 280, 42971-42977.

141. Schiff, M., Röckle, I., Burkhardt, H., Weinhold, B., and Hildebrandt, H. (2011) J. Neurosci. 31, 1302-1312.

142. Isomura, R., Kitajima, K., and Sato, C. (2011) J. Biol. Chem. 286, 21535-21545.

143. Lee, Y.-C., Kim, Y.-J., Lee, K.-Y., Kim, K.-S., Kim, B.-U., Kim, H.-N., Kim, C.-H., and Do, S.-I. (1998) Arch. Biochem. Biophys. 360, 41 $-46$.

144. Sato, C., Yasukawa, Z., Honda, N., Matsuda, T., and Kitajima, K. (2001) J. Biol. Chem. 276, 28849-28856.

145. Sato, C., Matsuda, T., and Kitajima, K. (2002) J. Biol. Chem. 277, 45299-45305.

146. Inoko, E., Nishiura, Y., Tanaka, H., Takahashi, T., Furukawa, K., Kitajima, K., and Sato, C. (2010) Glycobiology $20,916-928$.

147. Taniguchi, A. (2008) Curr. Drug Targets 9, 310-316.

148. Takashima, S., Tachida, Y., Nakagawa, T., Hamamoto, T., and Tsuji, S. (1999) Biochem. Biophys. Res. Commun. $260,23-27$. 
Profile of the Authors

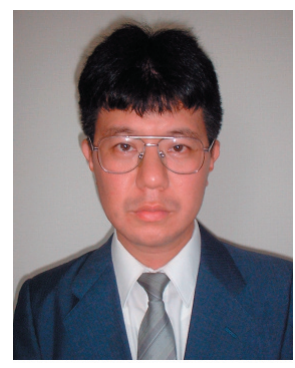

Shou Takashima received his PhD from the University of Tokyo in 1997. He then moved to The Institute of Physical and Chemical Research (RIKEN) as a research scientist and has been studying sialyltransferase genes and related glyco-genes. Now, he is a research scientist of the Laboratory of Glycobiology, The Noguchi Institute. He is interested in the physiological functions of glycogenes and glyco-chains

Shuichi Tsuji graduated from University of Tokyo in 1976 (M.S.), received his $\mathrm{PhD}$ in University of Tokyo in 1980. He started his professional carrier in 1978 as an assistant professor in the Department of Biochemistry, Faculty of Medicine, University of Tokyo. Then, he moved to The Institute of Physical and Chemical Research (RIKEN) as a Team Leader of Molecular Glycobiology of Frontier Research Program in 1991. Now, he is a professor of The Glycoscience Institute in Tokai University. His main research interests are elucidating the structural and functional relationships of sialyltransferase-family, and also studying the function of glycoconjugates using sialyltransferases and their genes. 